\title{
Indiana Jones and the Foreign Sovereign Immunities Act (FSIA): Interpreting FSIA's State Sponsored Terror Exception
}

\author{
Haley Claxton*
}

\section{INTRODUCTION}

In the opening scenes of Director Steven Spielberg's Indiana Jones and the Last Crusade, the movie's namesake hero, a young Indiana Jones fights to reclaim a long-lost golden crucifix, once owned by 16th century Spanish explorer Francisco Vázquez de Coronado, from a thief. ${ }^{1}$ Before attempting to reclaim the cross from the thief, Jones argues the point that curators, cultural heritage enthusiasts, and perhaps even the Seventh Circuit Court of Appeals of the United States would all agree with: "It belongs in a museum!" ${ }^{2}$ Echoing Dr. Jones's sentiment, the Seventh Circuit recently held in Rubin v. Islamic Republic of Iran that a collection of Persian antiquities, comprised of thousands of ancient and inscribed stone tablets, should remain in the collection of the University of Chicago's Oriental Institute. ${ }^{3}$ However, unlike Jones' attempt to keep the artifact from a thief, the court kept American victims of terrorist activity from seizing the tablets in order to satisfy legal judgments won against Iran. $^{4}$

Over the last two decades, U.S. courts have ruled that the Islamic Republic of Iran owes victims of state-sponsored terror nearly a billion

* J.D. Candidate, 2018, University of Kansas School of Law; B.A. History, Kansas State University, 2015. I would like to thank Beth Hanus, Tyler Childress, and Professor Ellen Sward for their valuable review and comments on this Comment, and all of the Kansas Law Review Board and Staff for their thorough editing and helpful suggestions. Special thanks to Cara Dehnert Huffman, KU Law alumna and Assistant Professor at Columbia College in Chicago for inspiring me to select this topic. Finally, thank you to my friends and family for always supporting me in every endeavor I undertake.

1. INDIANA JONES AND THE LAST CRUSADE (Lucasfilm Ltd. 1989).

2. Id. Later in the film, when the thief again reclaims the golden cross from Jones the line is repeated. Id. ("That belongs in a museum!").

3. Rubin v. Islamic Republic of Iran, 830 F.3d 470, $488-89$ (7th Cir. 2016), cert. granted in part, 137 S. Ct. 2326 (2017).

4. Id. at $473-75$. 
dollars in compensatory and punitive damages. ${ }^{5}$ Collecting the judgment amounts from Iran, however, remains an ongoing battle for most terrorvictim plaintiffs. ${ }^{6}$ Because Iran does not recognize the default judgments that U.S. courts have awarded these plaintiffs, the terror victims must instead attempt to recover the damages by attaching Iranian property, held within the jurisdiction of U.S. courts, to their judgments against Iran. ${ }^{7}$ This property includes blocked financial assets that American companies and banks owe Iran, as sought by the plaintiffs in the Ninth Circuit case Bennett v. Islamic Republic of Iran, and the Persian antiquities sought by the plaintiffs in Rubin. ${ }^{8}$

The Foreign Sovereign Immunities Act of 1976 ("FSIA") generally provides immunity from suit to foreign sovereigns, as well as immunity from attachment of their property in executing U.S. court judgments against them. ${ }^{9}$ However, FSIA provides limited exceptions to such immunity if the sovereign in question sponsored terrorist activity that is the basis of an American plaintiff's claim against them. ${ }^{10}$ If an exception applies, plaintiffs may attach property that belongs to the foreign sovereign and is located within the jurisdiction of American courts. ${ }^{11}$ The Seventh and Ninth Circuits have disagreed over the proper interpretation of the statute applying the state-sponsored terror exception to the usual immunity from attachment, codified at 28 U.S.C. $\S 1610(\mathrm{~g}){ }^{12}$ While the Ninth Circuit held in Bennett that $\S 1610(\mathrm{~g})$ is a "freestanding immunity exception," allowing terror victims to attach "any and all Iranian property [located] in the United States," a panel of the Seventh Circuit disagreed. ${ }^{13}$ In Rubin, the Seventh Circuit panel countered that $\$ 1610(\mathrm{~g})$ simply makes it easier for victims to seize particular "commercial use" property, designated elsewhere in $\S 1610$, but not any kind of Iranian property they

5. See, e.g., Bennett v. Islamic Republic of Iran, 825 F.3d 949, 956 (9th Cir. 2016) (calculating that "[c]ollectively, the judgments [against Iran in suits pertaining to state-sponsored terrorism] total nearly $\$ 1$ billion.").

6. Rubin, 830 F.3d at 473 .

7. See In re Islamic Republic of Iran Terrorism Litig., 659 F. Supp. 2d 31, $49-58$ (D.C. Cir. 2009) (explaining the difficulty of enforcing judgments against Iran and attempts to seize Iranian assets in numerous state-sponsored terrorism claims cases).

8. See Rubin, 830 F.3d at 474; Bennett, 825 F.3d at 957.

9. Rubin, 830 F.3d at 476-78; see also Foreign Sovereign Immunities Act of 1976, 28 U.S.C. $\S \S 1602-11(2012)$.

10. See 28 U.S.C. $\S \S 1605$ A, 1607 (2012).

11. See 28 U.S.C. $\S 1610$ (2012).

12. See Rubin, 830 F.3d at 487; cf. Bennett, 825 F.3d 949; see also infra Part II.B.

13. Bennett, 825 F.3d at 959, 966, 969 (Benson, J., concurring in part and dissenting in part); see also Rubin, 830 F.3d at 473. 
choose. ${ }^{14}$ The panel's decision created a circuit split and sought to overrule two prior Seventh Circuit cases, creating a novel procedural issue outside the scope of this Comment. ${ }^{15}$

The circuit split between the Seventh and Ninth Circuits is becoming increasingly prominent in the United States' foreign affairs. With the recent passing of the Justice Against State Sponsors of Terror Act ("JASTA"), Saudi Arabia is now considered a sponsor of terrorist acts occurring on U.S. soil for supporting the September 11th terrorist attacks on the World Trade Center in New York. ${ }^{16}$ JASTA provides victims of the attacks and their families a cause of action to sue Saudi Arabia for damages. ${ }^{17}$ With a growing number of potential plaintiffs able to bring

14. Rubin, 830 F.3d at $473-74$.

15. Because the majority panel opinion in Rubin "both create[d] a circuit split and overrule[d], in part, two recent decisions" of the Seventh Circuit, the Circuit's procedural Rule 40(e) would normally be triggered. Rubin, 830 F.3d at 489 (Hamilton, J., dissenting). Rule 40(e) requires that:

[a] proposed opinion approved by a panel of [the Seventh Circuit] adopting a position which would overrule a prior decision of this court or create a conflict between or among circuits shall not be published unless it is first circulated among the active members of this court and a majority of them do not vote to rehear en banc the issue of whether the position should be adopted.

7TH CIR. R. 40(e). In this case, however, five active judges, a majority, recused themselves, making it "impossible to hear [the] case en banc" or even to circulate the opinion as required. Rubin, 830 F.3d at 489 (Hamilton, J., dissenting). Neither the panel, nor Judge Hamilton, in dissent, indicated why the judges recused themselves, but "at least three of them have close ties to the University of Chicago." Noah Feldman, Ancient Treasures Shouldn't Be Compensation for Terror Victims, BLOOMBERGVIEW (July 25, 2016, 9:00 AM), https:/www.bloomberg.com/view/articles/2016-07-25/ancient-treasuresshouldn-t-be-compensation-for-terror-victims. While this novel situation has the potential to cause procedural wrinkles for the Seventh Circuit in the future, these issues are outside the scope of this Comment's analysis. See Eric Pearson, Coming Up Short: When There Aren 't Enough Judges Eligible to Rehear a Case En Banc, JD SUPRA (Sept. 19, 2016), http://www.jdsupra.com/legalnews/comingup-short-when-there-aren-t-19641/ (suggesting the novelty of not having enough eligible judges to rehear a case en banc).

16. Justice Against Sponsors of Terrorism Act, Pub. L. No. 114-222, 130 Stat. 852 (2016) (to be codified, in part, at 28 U.S.C. $\$ 1605 B$ ) [hereinafter JASTA]. See also Patricia Zengerle, Senate Passes Bill Allowing 9/11 Victims to Sue Saudi Arabia, REUTERS (May 17, 2016, 10:38 AM), https:/www.reuters.com/article/us-saudi-usa-congress/senate-passes-bill-allowing-9-11-victims-tosue-saudi-arabia-idUSKCN0Y8239.

17. JASTA, § 3, 130 Stat. at 853 (codified 28 U.S.C. $\S 1605 B(c)$ ). JASTA has proven controversial because of concerns that other nations may deny the United States immunity from suit in response. See, e.g., Scott Horsley \& Alisa Chang, Congress Overrides Obama's Veto On Sept. 11 Lawsuit Bill, NPR (Sept. 28, 2016, 3:22 PM), http://www.npr.org/2016/09/28/495709481/sept-11lawsuits-vote-today-could-be-first-reversal-of-an-obama-veto. This Act marked Congress's only override of a veto made by President Barrack Obama in his two-term presidency. Jennifer Steinhauer et al., Congress Votes to Override Obama Veto on 9/11 Victims Bill, N.Y. TIMES (Sept. 28, 2016), http:/www.nytimes.com/2016/09/29/us/politics/senate-votes-to-override-obama-veto-on-9-11victims-bill.html?_r=0. President Obama called the bill a "dangerous precedent" and a "mistake," indicating that the Act's potential aftermath could be harmful to diplomatic relations between the U.S. and a number of foreign entities. Id.; see infra note 217 and accompanying text. 
lawsuits under FSIA's terrorism exceptions, the need to clarify the scope of attachable property in these suits is more pressing than ever.

This Comment addresses the appropriate application of $\S 1610(\mathrm{~g})$. Based on statutory construction, legislative intent, the propriety of overruling Seventh Circuit precedent, and public policy concerns, courts should not interpret $\S 1610(\mathrm{~g})$ of FSIA as a freestanding immunity exception for attachment of any property belonging to state sponsors of terrorism. Instead, Courts should follow the Seventh Circuit and interpret $\S 1610(\mathrm{~g})$ to ease the attachment requirements for certain property which has a "commercial use," as designated elsewhere in $\S 1610 .{ }^{18}$

Part II of this Comment will provide background information relevant to examining the Ninth and Seventh Circuits' conflicting interpretations of $\S 1610(\mathrm{~g})$. Part III will analyze both decisions and argue that federal courts should adopt the Seventh Circuit's understanding of $\S 1610(\mathrm{~g})$, as described in Rubin, because of the statute's language and principles of statutory construction, legislative intent, and public policy concerns. Finally, Part IV will describe the ways the Seventh Circuit's decision could be implemented in the future.

\section{BACKGROUND}

Like any story of artifact seizure or protection, the history of the Bennet and Rubin cases and laws governing both is multi-faceted and full of twists, turns, and pitfalls. This part will introduce the practice of foreign sovereign immunity and the history of protecting international cultural property in the United States in Part II.A.1 and 2. Next, Part II.A.3 will explain the origins of FSIA and its statutory exceptions. Finally, Part II.B will discuss the Seventh and Ninth Circuits decisions creating a split over the function of FSIA $\S 1610(\mathrm{~g})$, the state-sponsored terror exception to foreign sovereign immunity from the attachment of property to execute judgments made by U.S. courts.

18. Rubin, 830 F.3d at $481-84$. 


\section{A. Foreign Sovereign Immunity, Cultural Property, and FSIA in the} U.S.

1. The History of Foreign Sovereign Immunity in the United States

Granting "foreign sovereign immunity" is the practice of allowing foreign nations or governments to avoid lawsuits filed against them in U.S. courts. ${ }^{19}$ Providing foreign sovereigns immunity from American judicial proceedings is "a matter of grace and comity rather than a constitutional requirement," but has a longstanding history in the United States. ${ }^{20}$ In 1812, Chief Justice John Marshall explained the purpose of providing foreign sovereign immunity: to maintain the "perfect equality and absolute independence of sovereigns, and th[e] common interest impelling them to mutual intercourse, and an interchange of good offices with each other ...."21 Congress did not formally regulate the practice of providing foreign sovereign immunity until the passage of the FSIA. ${ }^{22}$ The FSIA formalized the general provisions of foreign immunity U.S. courts previously developed in the common law and included exceptions to granting immunity in particular circumstances. ${ }^{23}$

2. Protection and Immunity of International Cultural Property in the United States

Just like the deeply rooted practice of providing foreign sovereigns immunity from suits in U.S. courts, the United States has also demonstrated a strong desire to protect various forms of cultural property

19. See E.H. Schopler, Annotation, Modern Status of the Rules as to Immunity of Foreign Sovereigns from Suit in Federal or State Courts, 25 A.L.R.3d 322, 322 (2016).

20. Bennett v. Islamic Republic of Iran, 825 F.3d 949, 954 (9th Cir. 2016) (quoting Republic of Austria v. Altmann, 541 U.S. 677, 689 (2004)); see generally Schooner Exch. v. McFaddon, 11 U.S. 116 (1812) (providing immunity to France in order to protect a French warship visiting U.S. ports due to storm damage, and establishing the practice of providing foreign sovereigns immunity in the U.S.); Michael A. Tessitore, Immunity and the Foreign Sovereign: An Introduction to the Foreign Sovereign Immunities Act, 73 FLA. B.J. 48, 48-50 (1999) (providing a brief history of foreign sovereign immunity in the United States).

21. Schooner, 11 U.S. at 137.

22. Foreign Sovereign Immunities Act, Pub. L. No. 94-583, 90 Stat. 2891 (1976) (codified as amended at 28 U.S.C. $\S \S 1330,1391(f), 1441(\mathrm{~d}), 1602-11$ (2012)); see also Tessitore, supra note 20, at 48 .

23. See Tessitore, supra note 20, at 48 ("The FSIA essentially codified the restrictive theory of immunity and established a comprehensive framework for resolving claims of immunity in any civil action against a foreign state or its political subdivisions, agencies, or instrumentalities."); see also infra Part II.A.3. 
in the United States and around the world in many ways, particularly in the last several decades. This concept has long had appeal in American pop culture. ${ }^{24}$ The U.S. government has also often manifested a strong desire to promote preservation and display of historical documents, sites, and cultural property, both at home, through entities like the National Archives, the Smithsonian Institution, and National Park Service, and abroad. $^{25}$ Additionally, Congress passed the Mutual Educational and Cultural Exchange Act in 1961, establishing the Bureau of Education and Cultural Affairs and the Fulbright Scholarship Program. ${ }^{26}$ Congress intended, in part,

to strengthen the ties which unite us with other nations by demonstrating the educational and cultural interests, developments, and achievements of the people of the United States and other nations ... and thus to assist in the development of friendly, sympathetic, and peaceful relations between the United States and the [rest of] the world. ${ }^{27}$

In addition to supporting educational purposes, protecting antiquities of international importance supports U.S. foreign relations efforts. For example, in 2016, U.S. Ambassador to the United Nations Samantha Power invited ambassadors from fifteen different countries, including Afghanistan, Algeria, Egypt, Iraq, Qatar, Senegal, and Palestine, to view an exhibit of Turkic artifacts on display at the Metropolitan Museum of Art in New York City. ${ }^{28}$ While viewing the exhibit, Powers "hope[d] the

24. Many American books and films sensationalize real or fictional protectors of historically and culturally important artifacts. See, e.g., Monuments MEN (Columbia Pictures \& Babelsburg Studio 2014) (based loosely on the actual stories of American military men reclaiming art looted by Nazis during WWII, as chronicled in ROBERT M. EDSEL \& BRET WitTER, MONUMENTS MEN: ALLiED Heroes, Nazi Thieves, and the Greatest Treasure Hunt in History (2007)); National TREASURE (Walt Disney Pictures 2004) (lead characters seek to find and protect a fabled "national treasure" trove based on clues left in America's founding documents); RAIDERS OF THE LOST ARK (Lucasfilm Ltd. 1981) (lead character, Indiana Jones, attempts to prevent Nazis from seizing the long lost Ark of the Covenant).

25. See, e.g., NAT'L ARChIVES, https://www.archives.gov/ (last visited Sept. 30, 2017) (providing information about the National Archives, which houses, displays, and preserves America's “Founding Documents"); NAT'L PARK SERV., https://www.nps.gov/index.htm (last visited Sept. 30, 2017) (providing links to the 413 different "areas" that the National Park Service maintains); Our Mission, SMitHSONIAN INST., https://www.si.edu/About/Mission (last visited Sept. 30, 2017) (listing "[v]aluing [w]orld [c]ultures" as one of their "[p]riorities" and "[s] haping the future by preserving our heritage, discovering new knowledge, and sharing our resources with the world" as their "[v]ision").

26. Mutual Educational and Cultural Exchange Act of 1961, Pub. L. 87-256, 75 Stat. 527 (1961) (codified at 22 U.S.C. $\S 2451$ ).

27. Id. $\S 101,75$ Stat. at 527 .

28. Pamela Falk, Museum Diplomacy: Could Islamic Art Inspire Middle East Peace?, OBSERVER (June 16, 2016，10:15 AM), http://observer.com/2016/06/museum-diplomacy-could- 
historic artworks would provide the edification needed to soften the tone of regional discord" between many of the nations whose ambassadors attended. ${ }^{29}$ There are numerous examples of "museum diplomacy," as well as attempts to maintain diplomatic relationships through lending artifacts to, and borrowing artifacts from, institutions all over the world for display. ${ }^{30}$

The first codification of cultural property protection in the United States was the Lieber Code in $1863 .{ }^{31}$ Later, in 1954, the United States signed the international Hague Convention for the Protection of Cultural Property in the Event of an Armed Conflict, which sought to "take all possible steps to protect cultural property" of other nations because of its "great importance for all peoples of the world." ${ }^{32}$ Most recently, in 2016, Congress enacted the Protect and Preserve International Cultural Property Act to better "protect and preserve international cultural property at risk" in war-torn Syria. ${ }^{33}$ Additionally, under the Immunity From Seizure Act ("IFSA"), passed in 2012, foreign artifacts "of cultural significance"

islamic-art-hold-the-key-to-peace-in-the-middle-east/.

29. Id.

30. See, e.g., Cristina Ruiz, Curators as Kissingers: Can Museums Repair Diplomatic Relations?, NEw REPUBLIC (Oct. 17, 2014), https://newrepublic.com/article/119884/how-museumsbecame-diplomatic-fixers (discussing museums serving as international diplomats, including the example of an exhibit in Libya after the fall of Gaddafi); see also Laina C. Lopez, Article: Art Loans by Foreign Countries, FOREIGN SOVEREIGN BLOG (Oct. 29, 2013), http://www.foreignsovereignblog.com/article-art-loans-by-foreign-countries/ (discussing the legal implications of art loans between the United States and foreign countries).

31. The Lieber Code arose out of the American Civil War and sought to protect "charitable institutions, collections, and works of art" from destruction by military forces during warfare. Patty Gerstenblith, The Destruction of Cultural Heritage: A Crime Against Property or a Crime Against People?, 15 J. Marshall Rev. Intell. Prop. L. 336, 338-39 (2016) (describing the Lieber Code's inclusion in an 1863 U.S. Army Field Manual).

32. Elizabeth Varner, The Art of Armed Conflicts: An Analysis of the United States' Legal Requirements Towards Cultural Property Under the 1954 Hague Convention, 44 CREIGHTON L. REV. 1185, 1188-89 (2011) (quoting Convention for the Protection of Cultural Property in the Event of Armed Conflict, May 14, 1954, 249 U.N.T.S. 240). The U.S. Senate ratified the 1954 Hague Convention in 2009. Id. at 1187. One explanation is that Congress feared the Hague Convention, unlike prior international treaties aiming to protect cultural property, would impose on the United States an affirmative duty to protect cultural property in occupied areas from destruction by third parties. See id. at 1187-88.

33. Protect and Preserve International Cultural Property Act of 2016, Pub. L. No. 114-151, 130 Stat. 369 (2016). Additional laws that protect international cultural property in the United States include: the 1970 United Nations Educational, Scientific and Cultural Organization's Convention on the Means of Prohibiting and Preventing the Illicit Import, Export, and Transfer of Ownership of Cultural Property, Nov. 14, 1970, 27 U.S.T. 37, 823 U.N.T.S. 231 (international agreement seeking to protect cultural property from theft and other "illicit" means of acquisition or sale of property), and the Convention on Cultural Property Implementation Act of 1983, Pub. L. 97-446, 96 Stat. 2329 (1982) (codified as amended at 19 U.S.C. $\S \S 2601-13$ (2012)) (ratifying the 1970 UNESCO Convention to better address archeological pillaging). 
temporarily loaned and imported to the United States for any non-profit "cultural exhibition, assembly, activity, or festival" hosted by any "educational institution" may be immune from "any judicial process" imposed by U.S. courts under particular conditions. ${ }^{34}$ However, if these conditions are not met and the loaning state is deemed a sponsor of terror, plaintiffs may seek to attach cultural property under FSIA in support of execution of U.S. judgments. ${ }^{35}$

\section{The Foreign Sovereign Immunities Act of 1976}

Congress passed the FSIA in 1976 to illuminate "clearer standards for resolving immunity questions" 36 and "to free the Government from the case-by-case diplomatic pressures" that arose in the courts. ${ }^{37}$ The FSIA dictates that foreign states, or their agencies and instrumentalities, are immune from the jurisdiction of both U.S. federal and state courts in almost all civil cases, but provides limited exceptions. ${ }^{38}$ Section 1610 of FSIA designates exceptions to immunity from property attachment, including providing for "state-sponsored terrorism" exceptions. ${ }^{39}$

FSIA's first state-sponsored terror exception to immunity was enacted in $1996{ }^{40}$ The original version of the exception was repealed and replaced

34. 22 U.S.C. $§ 2459$ (a) (2012). To receive immunity under IFSA, the "President or his designee" must (1) find an object is "of cultural significance," (2) find that the activity within the U.S. is "in the national interest," and (3) publish a notice indicating the findings in the Federal Register prior to importing the object. Id. If these conditions are met, any cultural object temporarily within U.S. jurisdiction may be immune from attachment. Id.

35. See id.; 28 U.S.C. § 1610 (2012); see also Rubin v. Islamic Republic of Iran, 830 F.3d 470, 473-79 (7th Cir. 2016), cert. granted in part, 137 S. Ct. 2326 (2017).

36. Tessitore, supra note 20, at 49 (citing Verlinden B.V. v. Cent. Bank of Nigeria, 461 U.S. 480, 488 (1983)).

37. Verlinden, 461 U.S. at 488 (providing an overview of FSIA's purposes).

38. 28 U.S.C. $\S \S 1604-1611$ (2012). Exceptions include $\S 1605$ (providing general exceptions to foreign sovereign immunity, including commercial interactions) and $\S 1605 \mathrm{~A}$ (providing an exception to foreign sovereign immunity for state-sponsored terror claims).

39. Exceptions to allowing state terror sponsors attachment immunity are 28 U.S.C. § 1610(a)(7) (2012) (state property "used for a commercial activity in the United States"), § 1610(b)(3) (pursuant to property of agencies or instrumentalities of state terror sponsors "engaged in commercial activity in the United States"), and $\S 1610$ (g) (as discussed in Part II.A.3.a.i). Other exceptions include $\S$ 1610(a)(1) (when a foreign state possessing property for commercial use waives their immunity), $\S$ 1610 (a)(2) (when attached property "is or was used for the commercial activity upon which the claim [was] based"), § 1610(a)(3)-(4) (when claims are related to property rights), § 1610(a)(5) (when claims are based on contractual agreements), and $\S 1610$ (a)(6) (when arbitral awards are related to the attached property).

40. Antiterrorism and Effective Death Penalty Act of 1996, Pub. L. No. 104-132, § 221, 110 Stat. 1214, 1241 (1996). The statute allowed U.S. citizens who were victims of terrorist activity supported by foreign sovereigns to sue for compensatory damages based on their injuries. However, 
to clarify a number of issues and is now codified at 28 U.S.C. $\S 1605 \mathrm{~A}$ and referred to as the "Flatow Amendment," and was passed in response to a terror attack involving Iran. ${ }^{41}$ The Flatow Amendment allows plaintiffs to seek punitive damages, along with compensatory damages, in suits against state terror sponsors. ${ }^{42}$ These plaintiffs faced many procedural challenges in filing suits against Iran. ${ }^{43}$ Even when plaintiffs were able to overcome the initial hurdles, most faced even more difficulty when attempting to recover their court ordered judgments. ${ }^{44}$ The court in In re Islamic Republic of Iran Terrorism Litigation attributed this difficulty to three primary factors: (1) the scarcity of "Iranian Government assets within the jurisdiction of United States Courts," (2) the immunity of many of the remaining Iranian assets located in the United States, and (3) the U.S. federal regulatory control of many of the assets attributed to state

the statute did not specify whether it "served as a basis for an independent federal cause of action against foreign state sponsors of terrorism" themselves, or merely provided causes of action against state officials, employees, and agents of a foreign state; nor did it specify if parties with state-sponsored terror claims could seek compensatory and punitive damages. In re Islamic Republic of Iran Terrorism Litig., 659 F. Supp. 2d 31, 42-43 (D.D.C. 2009). The FSIA's current state-sponsored terrorism exception clarifies these issues. See 28 U.S.C. § 1605(a)(7) (repealed 2008); see also In re Islamic Republic of Iran Terrorism Litig., 659 F. Supp. 2d at 40-43.

41. See Flatow v. Islamic Republic of Iran, 999 F. Supp. 1, 12 (D.D.C. 1998), abrogation recognized in Hartford Fire Ins. Co. v. Socialist People's Libyan Arab Jamahiriya, Civ. No. 98-3096 (TFH), 2007 WL 1876392 at *4 (D.D.C. June 28, 2007).

42. 28 U.S.C. $§ 1605$ A (2012). Congress passed the amendment in 1996 in response to an incident that later became the cause of action in Flatow, 999 F. Supp. at 6; see also In re Islamic Republic of Iran Terrorism Litig., 659 F. Supp. 2d at 41-46. The plaintiff, Stephen Flatow, participated in the passing of the Flatow Amendment and later filed suit on behalf of himself and his daughter, Alisa, under the provision. Flatow, 999 F. Supp. at 6-11. Alisa Flatow died from severe injuries caused by an Iran-funded suicide bombing on the Gaza Strip in 1995. Id. Flatow was the first case decided against Iran under the new Flatow Amendment and the FSIA state-sponsored terror exception. The D.C. District Court held that Iran owed Mr. Flatow approximately $\$ 247.5$ million in compensatory and punitive damages. In re Islamic Republic of Iran Terrorism Litig., 659 F. Supp. 2d at 44-45. The court also held that the state-sponsored terror exception and the Flatow Amendment "collectively established both subject matter jurisdiction and federal causes of action for civil lawsuits against state sponsors of terrorism." Id. at 44. The court, like Congress, displayed hope for the "popular sentiment" that "terrorism victims were going to "sue the terrorists out of business." Id. at 45 (internal citations omitted).

43. Applying the Flatow Amendment, the D.C. Circuit Court of Appeals held in Cicippio-Puleo v. Islamic Republic of Iran that the amendment only created "a cause of action against . . officials, employees, and agents" of a foreign state, but not against a state itself. 353 F.3d 1024, 1035-36 (D.C. Cir. 2004) (emphasis in original). Because of this, plaintiffs with claims pertaining to state-sponsored terror began to seek causes of action under state tort law from the states in which they were domiciled at the time of the terror attack. In re Islamic Republic of Iran Terrorism Litig., 659 F. Supp. 2d at 4648. This was successful in some cases, but entirely precluded many other plaintiffs from finding relief in states without an appropriate or applicable statutory cause of action. Id.

44. See, e.g., In re Islamic Republic of Iran Terrorism Litig., 659 F. Supp. 2d at 49 (listing prior cases in which plaintiffs attempted to attach Iranian assets, in addition to the consolidation of cases at issue in the case itself). 
sponsors of terror and located in the United States. ${ }^{45}$ Receiving the judgment amount directly from the Iranian Government was improbable because the Government had never appeared in any FSIA terrorism action. $^{46}$ This led plaintiffs to "locate and attach Iranian Government assets in aid of execution of their civil judgments," a Herculean feat in light of the scarcity of such assets in the United States. ${ }^{47}$ The scarcity of Iranian assets within the jurisdiction of U.S. courts arises primarily from the 1979 Iranian Hostage Crisis and its aftermath. ${ }^{48}$ Most Iranian assets remaining in the United States after the resolution of the Crisis were "subject to a dizzying array of statutory and regulatory authorities," and with a tense political relationship between the United States and Iran, plaintiffs had few options for attachment. ${ }^{49}$ To combat what one court deemed "the never-ending struggle to enforce judgments against Iran," Congress passed several pieces of legislation, including Section 201 of the Terrorism Risk Insurance Act of 2002 ("TRIA"), Section 1083 of the 2008 National Defense Appropriations Act ("2008 NDAA"), and Section 502 of the Iran Threat Reduction and Syria Human Rights Act of 2012. ${ }^{50}$

Section 201 of TRIA allows terror victims to satisfy their judgments by seizing assets that belong to state sponsors of terror, but are frozen or seized by the U.S. government, "notwithstanding any other provision of law." 51 TRIA explicitly excludes "property... used exclusively for

45. Id. at 62; see also infra note 48 (explaining federal regulation of Iranian assets in U.S.).

46. Id. at 43 n. 5 (explaining that "[w]hile Iran has not defended itself in any of the lawsuits under the terrorism exception, Iran has on occasion come to court to prevent plaintiffs from collecting on default judgments entered under that provision.").

47. See id. at 49-50 (providing an overview of the Iranian Hostage Crisis and its role in limiting Iranian assets in the U.S.).

48. In response to the Iranian capture of the U.S. embassy and embassy personnel in Tehran in November 1979, President Carter froze all Iranian assets located within the United States. Id. The crisis was eventually resolved by the signing of the Algiers Accords in 1981, in which Iran agreed to return the American hostages in exchange for an agreement that the U.S. would unfreeze Iran's assets. $I d$. at 50. Both nations also agreed to settle all litigation between their governments and "any outstanding litigation between the nationals of the two countries." Id. The United States was further required to return Iranian assets held in American banks. See id. (citing Dames \& Moore v. Regan, 453 U.S. 654, 665-66 (1981) (validating the President's executive orders implementing the provisions of the Algiers Accords)).

49. Id. at 52 .

50. Id. at 49-62; Iran Threat Reduction and Syria Human Rights Act of 2012, Pub. L. No. 112$158, \S 502,126$ Stat. 1214, 1258 (2012) (codified at 22 U.S.C. $\$ 8772$ (2012)); 2008 National Defense Appropriations Act, Pub. L. No. 110-181, § 1083, 122 Stat. 3, 338 (2008) (codified at 28 U.S.C. §§ 1605 A, 1610 (2012)); Terrorism Risk Insurance Act of 2002, Pub. L. No. 107-297, § 201(a), 116 Stat. 2322, 2337 (2002) (codified as amended at 28 U.S.C. § 1610 (2012)).

51. See TRIA $\S 201$ (a). 
diplomatic or consular purposes" from attachment. ${ }^{52}$ Section 8772 of the Iran Threat Reduction and Syria Human Rights Act of 2012, codified at 22 U.S.C. $\S 8772$, was the key statute at issue in the recent Supreme Court case Bank Markazi v. Peterson. ${ }^{53}$ The Court held that 22 U.S.C. $\S 8772$ made about $\$ 1.75$ billion in Iranian assets held in a New York bank specifically available to "partially satisfy judgments gained in separate actions by over 1,000 victims of terrorist acts sponsored by Iran," including the plaintiffs in the Rubin case discussed in Section II.B.2. ${ }^{54}$ While the defendants argued that $\S 8772$ was unconstitutional for violating the separation of powers between the legislative and judicial branches, the majority of the Court disagreed and upheld the legislation. ${ }^{55}$ In effect, the Court's decision indicates that Congress may intervene to designate particular assets for attachment in cases related to victims of statesponsored terror. ${ }^{56}$

The effect of Section 1083 of the 2008 NDAA was much broader than either TRIA Section 201 or Section 502 of the Iran Threat Reduction and Syria Human Rights Act. ${ }^{57}$ The primary results of Section 1083 were the re-codification of the Flatow Amendment as 28 U.S.C. $\S 1605 \mathrm{~A}$ and the addition of language to $\S 1610$, including subsection $1610(\mathrm{~g})$, for "Property in Certain Actions.",58

The Flatow Amendment, or $\S 1605 \mathrm{~A}$, is the current exception to sovereign immunity for state sponsors of terrorism, and it expressly creates a federal cause of action allowing victims of terror to sue state sponsors of terror directly. ${ }^{59}$ Generally, to file suit under $\S 1605 \mathrm{~A}$ : (1) the terror victim must be a U.S. national, ${ }^{60}(2)$ the nation sued must be recognized as a "state sponsor of terrorism" by the U.S. Secretary of State, prior to or resulting

52. Id. § 201(d)(2)(B)(ii); see also Hegna v. Islamic Republic of Iran, 287 F. Supp. 2d 608, 60910 (D. Md. 2003), aff'd, 376 F.3d 226 (4th Cir. 2004) (holding that property once occupied by Iranian diplomats was not attachable under the Terrorism Risk Insurance Act of 2002).

53. See 136 S. Ct. 1310, 1314-16 (2016).

54. Id. at 1316; see also infra Section II.B.2.

55. See id. at 1322-29.

56. See id.

57. See In re Islamic Republic of Iran Terrorism Litig., 659 F. Supp. 2d 31, $58-62$ (D.D.C. 2009) (explaining the effect of 2008 NDAA $\S 1083$ ).

58. See id. (explaining the effect of 2008 NDAA § 1083); 28 U.S.C. $§ 1605 A$ (2012); 28 U.S.C. $\S 1610$ (2012); see also discussion infra Section II.A.3.(a).i.

59. 28 U.S.C. $\S 1605 \mathrm{~A}(\mathrm{a})(1)$, (c); see supra notes 37-38 and accompanying text.

60. $\S 1605 \mathrm{~A}(\mathrm{a})(2)(\mathrm{A})(\mathrm{ii})(\mathrm{I})-(\mathrm{III}) . \quad$ Members of the U.S. military and U.S. government employees or employees acting under a contract awarded by the U.S., attacked while within the scope of his or her employment, may also sue under $\S 1605 \mathrm{~A}$. Id. 
from the basis of the plaintiff's claims, ${ }^{61}$ and (3) the designated state sponsor of terrorism must be responsible for the "personal injury or death [of the plaintiff] caused by an act of torture, extrajudicial killing, aircraft sabotage, [or] hostage taking," or for providing "material support or resources for" the act which provides the basis for the plaintiff's claim. ${ }^{62}$ In addition to defining when plaintiffs may bring suits against state sponsors of terror, $\S 1605 \mathrm{~A}(\mathrm{~g})$ establishes a lien against certain property in judicial proceedings against the sued state as soon as plaintiffs file notice of the proceeding. ${ }^{63}$ The lien is established against "any real property or tangible personal property" which is (1) subject to attachment in order to satisfy a judgment pursuant to 28 U.S.C. $\S 1610$, (2) located within the judicial district of the filing, and (3) titled "in the name of any defendant," or essentially property of the foreign sovereign being sued. ${ }^{64}$

Section 1610 includes exceptions to foreign immunity from attachment of assets in aid of execution of judgments entered by U.S. courts. ${ }^{65}$ Congress intended to combat "the inability of plaintiffs to execute their civil judgments against Iran" by adding language to the section as part of the 2008 NDAA. $^{66}$ Section 1610(a) lists the kinds of attachable property used for "commercial activity" by terror sponsors on American soil, and most importantly denies immunity from attachment to such property when the judgment against the state relates to "claim[s] for which the foreign state is not immune under" the state-sponsored terror exception, $\S 1605 \mathrm{~A}^{67}$ Section $1610(\mathrm{~b})(3)$ also denies immunity from attachment to agencies or instrumentalities of states designated as sponsors of terror under $\S 1605 \mathrm{~A} .{ }^{68}$ Several courts maintain that $\S$ 1610(b)(3) includes state instrumentalities generally considered "juridically separate," or apart from a state's underlying government for the purposes of suit, in order to "avoid the injustice that would result from

61. $\S 1605 \mathrm{~A}(\mathrm{a})(2)(\mathrm{A})(\mathrm{i})(\mathrm{I})-(\mathrm{II})$. The State Department designated Iran a state sponsor of terrorism on January 19, 1984. State Sponsors of Terrorism, U.S. DEP'T OF ST. (last visited Oct. 5, 2017), http://www.state.gov/j/ct/list/c14151.htm. Iran currently maintains this designation, along with Syria and the Sudan. Id.

62. $\S 1605 \mathrm{~A}(\mathrm{a})(1)$.

63. $\S 1605 \mathrm{~A}(\mathrm{~g})(1)$.

64. $\S 1605 \mathrm{~A}(\mathrm{~g})(1)(\mathrm{A})-(\mathrm{C})$.

65. 28 U.S.C. $\S 1610(2012)$.

66. In re Islamic Republic of Iran Terrorism Litig., 659 F. Supp. 2d 31, 62 (D.D.C. 2009).

67. $\S 1610(a)(7)$. Thus, if a state is deemed a state sponsor of terror, and therefore barred from immunity under $\S 1605 \mathrm{~A}$, property owned by that state, located in the United States, and used for some commercial purpose is not immune from attachment in claims brought against the state on the basis of terrorism related activity. $I d$.

68. §1610(b)(3). 
permitting a foreign state to reap the benefits of [American] courts while avoiding the obligations of international law." $" 69$

Section 1610(g), titled "Property in Certain Actions" also pertains directly to states denied immunity under the Flatow Amendment. ${ }^{70}$ While the court's opinion in In re Islamic Republic of Iran Litigation indicated that $\S 1610(\mathrm{~g})$ was "plainly intended to limit the application of foreign sovereign immunity... to attachment or execution with respect to property belonging to designated states [sic] sponsors of terrorism," the court also found that the "full implications of $\S 1610(\mathrm{~g})$ [were] far from clear." "' Section $1610(\mathrm{~g})(1)$ reads:

(1) In general ... the property of a foreign state against which a judgment is entered under section $1605 \mathrm{~A}$, and the property of an agency or instrumentality of such a state, including property that is a separate juridical entity or is an interest held directly or indirectly in a separate juridical entity, is subject to attachment in aid of execution, and execution, upon that judgment as provided in this section, regardless of-

(A) the level of economic control over the property by the government of the foreign state;

(B) whether the profits of the property go to that government;

(C) the degree to which officials of that government manage the property or otherwise control its daily affairs;

(D) whether that government is the sole beneficiary in interest of the property; or

(E) whether establishing the property as a separate entity would entitle the foreign state to benefits in United States courts while avoiding its obligations. $^{72}$

Subsections $1610(\mathrm{~g})(1)(\mathrm{A})-(\mathrm{E})$ are often referred to as the "Bancec factors." Courts derived the Bancec factors from the Supreme Court's

69. First Nat'l City Bank v. Banco Para El Comercio Exterior de Cuba, 462 U.S. 61 1, 634 (1983) [hereinafter Bancec] (holding that in suits against state-sponsors of terror, disregarding the "normally separate juridical status of a government instrumentality" is justifiable to promote fairness and justice); see infra notes $72-77$ and accompanying text.

70. $\S 1610(\mathrm{~g})$.

71. In re Islamic Republic of Iran Terrorism Litig., 659 F. Supp. $2 \mathrm{~d}$ at 62.

72. $\S 1610(\mathrm{~g})(1)$.

73. See, e.g., Rubin v. Islamic Republic of Iran, 830 F.3d 470, 482 (7th Cir. 2016), cert. granted in part, 137 S. Ct. 2326 (2017) (citing Flatow v. Islamic Republic of Iran, 308 F.3d 1065, 1071 n.9 (9th Cir. 2002); Walter Fuller Aircraft Sales, Inc. v. Republic of Philippines, 965 F.2d 1375, 1380-82, 
opinion in First National City Bank v. Banco Para El Comercio Exterior De Cuba (Bancec).$^{74}$ The Bancec doctrine created a "general presumption that a judgment against a foreign state may not be executed on property owned by a juridically separate agency or instrumentality," but included two distinct exceptions to this immunity when "the sovereign and its instrumentality are alter egos or if adherence to the rule of separateness would work an injustice., ${ }^{75}$ In applying Bancec, courts created a list of five general factors to determine if an exception applied to a juridically separate agency or instrumentality. ${ }^{76}$ Those factors include:

(1) The level of economic control by the government;

(2) whether the entity's profits go to the government;

(3) the degree to which government officials manage the entity or otherwise have a hand in its daily affairs;

(4) whether the government is the real beneficiary of the entity's conduct; and

(5) whether adherence to separate identities would entitle the foreign state to benefits in United States courts while avoiding its obligations. ${ }^{77}$

In interpreting $\S 1610(\mathrm{~g})$, both the Seventh and Ninth Circuits recognized Congress's intent to mirror the Bancec factors in $\S$ $1610(\mathrm{~g})(1)(\mathrm{A})-(\mathrm{E}) .^{78}$

Section $1610(\mathrm{~g})(2)$ governs assets that qualify under subsection (1), but are blocked by the U.S. government specifically under the Trading With the Enemy Act or the International Emergency Economic Powers Act. ${ }^{79}$ Finally, $\S 1610(\mathrm{~g})(3)$ governs potential third-party joint property

1380-81 n.7 (5th Cir. 1992)).

74. Bancec, 462 U.S. at 626-29; see also Rubin, 830 F.3d at 481-86.

75. Rubin, 830 F.3d at 481-82 (citing Bancec, 462 U.S. at 628-33); see also Flatow, 308 F.3d at $1071 \mathrm{n} .9$.

76. Rubin, 830 F.3d at 482 (citing Flatow, 308 F.3d at 1071 n.9; Walter, 965 F.2d at 1380-82, 1380 n.7) (explaining that "[s]oon after Bancec was decided, the federal courts began to coalesce around a set of five factors for determining when the exceptions applied").

77. Id.

78. See Bennett v. Islamic Republic of Iran, 825 F.3d 949, 955 (9th Cir. 2016) (comparing $\S$ 1610 (g) and Bancec); Rubin, 830 F.3d at 483 (indicating that the strong similarity in language between the Bancec factors and $\S 1610(\mathrm{~g})(1)$ was intended to "abrogate the Bancec doctrine for terrorismrelated judgments").

79. 28 U.S.C. $§ 1610(\mathrm{~g})(2)$ (2012) ("United States sovereign immunity inapplicable. Any property of a foreign state, or agency or instrumentality of a foreign state, to which paragraph (1) 
holders, who may be non-liable under the suit and inappropriately punished if certain property is seized. ${ }^{80}$

In the past, $\S 1610(\mathrm{~g})$ was consistently used by the courts to punish state sponsors of terrorism because it allows for the attachment of certain assets "regardless of factors that would ordinarily insulate such assets in other contexts governed by $\S 1610$ (a) or (b)." 81 However, other courts, including the Fourth Circuit, have held that a "plain reading of $\S 1610(\mathrm{~g})$ offers no indication that Congress intended to eliminate the immunity that has long been afforded to diplomatic properties, like Iran's former embassy here in the United States ...." ${ }^{82}$ Currently, the courts in the Seventh and Ninth Circuits have conflicting interpretations of $\S 1610(\mathrm{~g}) .^{83}$ The Ninth Circuit held that $\S 1610(\mathrm{~g})$ is a "freestanding exception" to immunity, making any property attachable under $\S 1610(\mathrm{~g})$, regardless of the commercial use requirements of $\S 1610$ (a) and (b). ${ }^{84}$ Conversely, the Seventh Circuit said $\S 1610(\mathrm{~g})$ 's only purpose is to remove the Bancec

applies shall not be immune from attachment in aid of execution, or execution, upon a judgment entered under section 1605A because the property is regulated by the United States Government by reason of action taken against that foreign state under the Trading With the Enemy Act or the International Emergency Economic Powers Act.”).

80. $\S 1610(\mathrm{~g})(3)$ ("Third-party joint property holders.-Nothing in this subsection shall be construed to supersede the authority of a court to prevent appropriately the impairment of an interest held by a person who is not liable in the action giving rise to a judgment in property subject to attachment in aid of execution, or execution, upon such judgment."); see also Weinstein v. Islamic Republic of Iran, 831 F.3d 470 (D.C. Cir. 2016). In Weinstein, American victims of Iranian, North Korean, and Syrian terrorist acts sought to seize IP addresses owned jointly by those nations and the U.S. based Internet Corporation for Assigned Names and Numbers ("ICANN") to satisfy default judgments against the nations. Id. at 473-77. The court held that while $\S 1610(\mathrm{~g})(1)$ might allow for the attachment of any applicable property, $\S 1610(\mathrm{~g})(3)$ protects the property interests of a third-party owner if those interests are particularly strong and the third-party was in no way related to the terror acts. Id. at 486 .

81. Gates v. Syrian Arab Republic, 755 F.3d 568, 576 (7th Cir. 2014), overruled by Rubin, 830 F.3d at 487; see also Wyatt v. Syrian Arab Republic, 800 F.3d 331, 343 (7th Cir. 2015), overruled by Rubin, 830 F.3d at 487 (upholding the understanding of $\S 1610(\mathrm{~g})$ provided in Gates).

82. In re Islamic Republic of Iran Terrorism Litig., 659 F. Supp. 2d 31, 102 (D.D.C. 2009); see also Hegna v. Islamic Republic of Iran, 287 F. Supp. 2d 608, 609 (D. Md. 2003), aff'd on other grounds, 376 F.3d 226 (4th Cir. 2004) (holding that property once occupied by Iranian diplomats was not attachable under the Terrorism Risk Insurance Act of 2002, and further unattachable under FSIA); Bennett v. Islamic Republic of Iran, 604 F. Supp. 2d 152, 162 (D.D.C. 2009), aff'd, 618 F.3d 19 (D.C. Cir. 2010) (holding $\S 1610(\mathrm{~g})$ does not indicate that "diplomatic properties are [] subject to attachment").

83. Bennett, 825 F.3d at $960 ;$ Rubin, 830 F.3d at $487-88$.

84. Bennett, 825 F.3d at 960; see also Weinstein, 831 F.3d at 483 ("Once a section 1605A judgment is obtained, section $1610(\mathrm{~g})$ strips execution immunity from all property of a defendant sovereign."); Kirschenbaum v. 650 Fifth Ave. \& Related Props., 830 F.3d 107, 123 (2d Cir. 2016) ("Section $1610(\mathrm{~g})$ strips FSIA attachment immunity from the property of a 'foreign state' or of its 'agency or instrumentality' if the underlying judgment was entered under $\S 1605 \mathrm{~A}$ 's terrorism exception.”), cert. denied, Alavi Found. v. Kirschenbaum, 137 S. Ct. 1332 (2017). 
considerations required to attach property under $\S 1610$ (a) and (b) in claims related to state-sponsored terror. ${ }^{85}$

\section{B. Bennett and Rubin: Opposing Readings of $\$ 1610(\mathrm{~g})$ in the Ninth and Seventh Circuits}

This section reviews the Ninth and Seventh Circuits' opinions in Bennett and Rubin. Section B.1 will outline the facts and litigation history of Bennett and the Ninth Circuit's analysis and holding in the case. Section B.2 will describe the facts of the Rubin case, with emphasis on the Persepolis Collection, the litigation history of the case, and the Seventh Circuit's analysis and holding.

1. Bennett v. Islamic Republic of Iran

\section{a. Facts and Litigation History}

In Bennett v. Islamic Republic of Iran, Michael and Linda Bennett filed suit on behalf of their daughter, Maria, a student at the Hebrew University of Jerusalem in Israel. ${ }^{86}$ While Maria attended the University in 2002, an offshoot of Hamas, a terrorist organization supported by Iran, bombed the cafeteria, fatally injuring Maria and other students. ${ }^{87}$ In 2007, a district court ruled the Bennetts were entitled to almost thirteen million dollars in damages from Iran, based on Iran's role in the terror attack. ${ }^{88}$ Over the next several years, the Bennetts unsuccessfully attempted to attach Iranian assets pursuant to the 2008 additions to FSIA $\S 1610$ to satisfy their judgment. ${ }^{89}$ These assets included the former Iranian Embassy, which the courts refused to attach for diplomatic reasons. ${ }^{90}$ Eventually, the Bennetts sought to attach approximately $\$ 17.6$ million which U.S. based companies, Visa, Inc. ("Visa") and Franklin Resources, Inc. ("Franklin"), owed to Bank Melli, the largest financial institute in and considered an instrumentality of, Iran. ${ }^{91}$ Visa and Franklin owed Bank Melli funds under a contract involving the use of Visa credit cards in

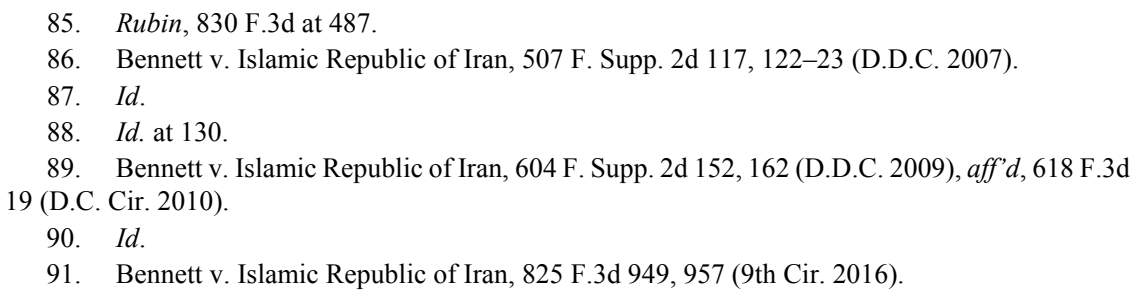


Iran. ${ }^{92}$ The district court held these funds were attachable under section 201(a) of TRIA, because the funds sought were frozen by the U.S. government, and under $\S 1610(\mathrm{~g})$ of the FSIA. ${ }^{93}$ The defendants, including Bank Melli, appealed to the Ninth Circuit, where a three-judge panel heard the appeal, two judges affirming the district court's ruling and one concurring in part and dissenting in part. ${ }^{94}$

b. The Ninth Circuit's Analysis and Ruling

The two judges affirming the district court first held that TRIA $\S$ 201(a) was an appropriate means to attach the funds sought because the funds were blocked by the U.S. government. ${ }^{95}$ The court also held that Bank Melli, an "instrumentality" of Iran, was not immune to attachment because the underlying claim arose as a result of state-sponsored terror. ${ }^{96}$ The majority next considered the potential attachment of the Visa and Franklin funds under $\S 1610(\mathrm{~g}) .{ }^{97} \quad$ While the panel in dicta "acknowledge[d] that $\S 1610$ as a whole [was] ambiguous," it nevertheless held that $\S 1610(\mathrm{~g})$ was a freestanding exception to immunity from attachment of assets in claims arising under $\S 1605 \mathrm{~A}$ and incidents of state sponsored terror. ${ }^{98}$ In effect, this holding would mean that any property of Iran, or an entity of Iran, is attachable under $\S 1610(\mathrm{~g})$. The Ninth Circuit's interpretation markedly diverged with the United States', as amicus curiae, interpretation of $\S 1610(\mathrm{~g}) .^{99}$ The United States argued "section $1610(\mathrm{~g})$ is not a freestanding exception to immunity that can be invoked independent of the rest of section 1610."100 In other words, the United States argued that $\S 1610(\mathrm{~g})$ simply eases the requirements for property attachable under other subsections of the rule, particularly $\S$

\footnotetext{
92. Id.

93. Id.; Bennett v. Islamic Republic of Iran, 927 F. Supp. 2d 833, 845-46 (N.D. Cal. 2013); see also supra notes 50-52 and accompanying text (discussing TRIA § 201).

94. Bennett, 825 F.3d at 954.

95. Id. at $957-58$.

96. Id. at 958 .

97. Id. at $958-64$.

98. Id. at 961

99. Id. at 961 n. 7; see also Brief for the United States as Amicus Curiae Supporting Neither Party at 10, Bennett v. Islamic Republic of Iran, 825 F.3d 949 (9th Cir. 2016) (Nos. 13-15442, 13 16100) ("[I]f a plaintiff covered by section $1610(\mathrm{~g})$ wishes to attach the assets of a state agency or instrumentality, and the plaintiff can find an exception in section 1610 that would apply but for the fact that the plaintiff holds a judgment against the state itself-rather than an entity that would be considered legally distinct - the plaintiff would be able to proceed.").
}

100. See id. at 8 . 
1610(a) and (b) when the claims are against state terror sponsors. ${ }^{101}$

Disagreeing with the United States' interpretation, the court first contended that "Congress was referring to, and abrogating," not only the presumption that instrumentalities were generally immune from suits against the state to which they were an instrumentality, but also the usual application of the Bancec factors to instrumentalities. ${ }^{102}$ The majority held that $\S 1610(\mathrm{~g})$ "contain[ed] a freestanding provision for attaching and executing against assets of a foreign state or its agencies or instrumentalities," regardless of the requirements of any other subsection of $\S 1610$, including the requirements for revoking immunity for property used for, "commercial activity" in $\S 1610$ (a) and (b). ${ }^{103}$ The court stated that $\S 1610(\mathrm{~g})$ dealt with subject matter distinct from other parts of the section because " $[\S 1610(\mathrm{~g})]$ applies only to 'certain actions,' specifically, judgments 'entered under section 1605A.",104 Indicating "the particular... controls over the general," the panel thus held that by applying $\S 1610(\mathrm{~g})$, attachments need not meet the "commercial use" requirements in subsections (a) or (b) and in effect, indicated that any property could be seized pursuant to $\S 1610(\mathrm{~g})$, regardless of its characteristics of uses. ${ }^{105}$

Next, the court determined that "as provided in this section" referred only "to procedures contained in" the subsection of $\S 1610$ directly preceding $\S 1610(\mathrm{~g})$, but not to $\S 1610$ as a whole or other provisions within the FSIA. ${ }^{106}$ The preceding subsection, $\S 1610(\mathrm{f})$, allows for the attachment of certain blocked assets of state sponsors of terror. ${ }^{107}$ The

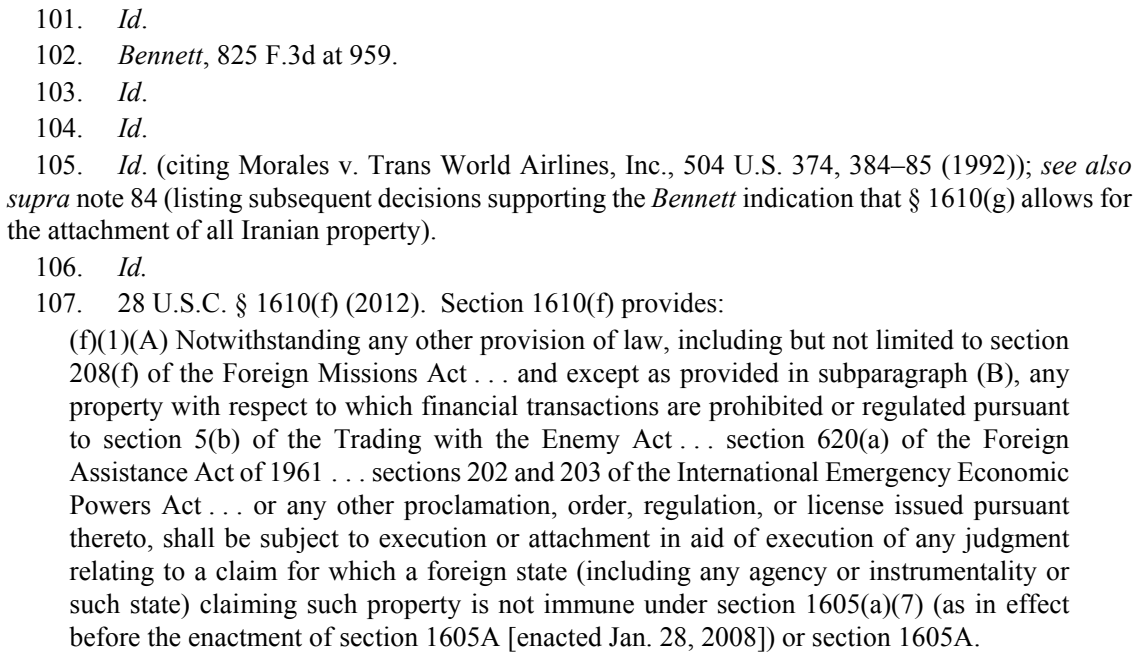


majority further denied that their reading of $\S 1610(\mathrm{~g})$ made references to the state terror exception $\S 1605 \mathrm{~A}$ in $\S 1610(\mathrm{a})(7)$ and $\S 1610(\mathrm{~b})(3)$ superfluous, relying on two Seventh Circuit cases: Gates v. Syrian Arab Republic and Wyatt v. Syrian Arab Republic. ${ }^{108}$ In Gates, the Seventh Circuit held that $\S 1610(\mathrm{~g})$ "allow[ed] attachment of a much broader range of assets to satisfy [ $\S 1605$ A related] judgments" than $\S 1610$ (a) or (b). ${ }^{109}$ In Wyatt, the Seventh Circuit held that plaintiffs proceeding under $\S$ $1610(\mathrm{~g})$ need not comply with the FSIA $\S 1608(\mathrm{e})$, which relates to attachment of foreign owned real estate in preferred mortgage foreclosures. ${ }^{110}$ The Ninth Circuit majority also relied on "Congress' intention to make it easier for victims of terrorism to recover judgments," evidenced by statements made by one of the sponsors of the 2008 NDAA bill, Senator Frank Lautenberg. ${ }^{11}$

In his partial dissent, Judge Dee V. Benson agreed that TRIA permitted the attachment of the funds at issue, but disagreed that $\S 1610(\mathrm{~g})$ was a freestanding immunity exception. ${ }^{112}$ Judge Benson concluded that in enacting $\S 1610(\mathrm{~g})$, "Congress did not . . . intend to open the floodgates and allow terrorism plaintiffs to attach any and all Iranian property in the

(B) Subparagraph (A) shall not apply if, at the time the property is expropriated or seized by the foreign state, the property has been held in title by a natural person or, if held in trust, has been held for the benefit of a natural person or persons.

(2)(A) At the request of any party in whose favor a judgment has been issued with respect to a claim for which the foreign state is not immune under section 1605(a)(7) (as in effect before the enactment of section 1605A [enacted Jan. 28, 2008]) or section 1605A, the Secretary of the Treasury and the Secretary of State should make every effort to fully, promptly, and effectively assist any judgment creditor or any court that has issued any such judgment in identifying, locating, and executing against the property of that foreign state or any agency or instrumentality of such state.

(B) In providing such assistance, the Secretaries-

(i) may provide such information to the court under seal; and

(ii) should make every effort to provide the information in a manner sufficient to allow the court to direct the United States Marshall's office to promptly and effectively execute against that property.

(3) Waiver. The President may waive any provision of paragraph (1) in the interest of national security.

Id.

108. Bennett, 825 F.3d at 959-62.

109. Gates v. Syrian Arab Republic, 755 F.3d 568, 576 (7th Cir. 2014), overruled by Rubin v. Islamic Republic of Iran, 830 F.3d 470, 487 (7th Cir. 2016).

110. Wyatt v. Syrian Arab Republic, 800 F.3d 331, 343 (7th Cir. 2015), overruled by Rubin v. Islamic Republic of Iran, 830 F.3d 470, 487 (7th Cir. 2016); see also Bennett, 825 F.3d at 960-61.

111. Bennett, 825 F.3d at 960-62 (citing 154 Cong. Rec. S54-01 (Jan. 22, 2008) (statement of Sen. Lautenberg) (indicating that the purpose of the bill, and $\S 1610(\mathrm{~g})$ particularly, was to make it easier for terror victims to collect the judgment amounts owed to them)).

112. Id. at 966-69 (Benson, J., concurring in part and dissenting in part). 
United States ... [but] intended the commerce limitation [of $\S 1610(a)$ ] to remain in place."113 Judge Benson also recognized the role the Ninth Circuit's opinion might play in the Seventh Circuit's disposition in Rubin a few months later. ${ }^{114}$ Judge Benson wrote "[s]urely this Court's holding will be argued as precedent to allow the Rubin plaintiffs to seize Persian artifacts to be auctioned off to satisfy the Rubin plaintiffs' default judgments . . . an unjustified and unfortunate result." 115

2. Rubin v. Islamic Republic of Iran

a. Facts and Litigation History

The plaintiffs in the Rubin cases have been in and out of litigation since filing their initial suit, Campunzo v. Islamic Republic of Iran, in 2001. ${ }^{116}$ The initial suit was brought by or on behalf of eight U.S. citizens, including the Rubins, who were victims of Hamas suicide bombers in Jerusalem in September 1997. ${ }^{117}$ The district court found these plaintiffs were entitled to a total $\$ 71.5$ million default judgment, which Iran subsequently refused to pay. ${ }^{118}$ Over the next thirteen years, plaintiffs from the Campunzo suit joined with the Rubins and attempted to satisfy their judgments by attaching Iranian assets, including collections of Persian antiquities in the possession of various American museums within the jurisdictions of the First and Seventh Circuits. ${ }^{119}$ The First Circuit held that antiquities originating from Iran and housed at the Boston Museum of Fine Arts and Harvard University could not be attached because they did

\footnotetext{
113. Id. at 969

114. Id.

115. Id.

116. See Campuzano v. Islamic Republic of Iran, 281 F. Supp. 2d 258, 261 (D.D.C. 2003) (initiating action to secure damages from Iran for injuries sustained from a state-sponsored terror attack in which the Rubins were among the plaintiffs); see also Jennifer Anglim Kreder \& Kimberly Degraaf, Museums in the Crosshairs: Unintended Consequences of the War on Terror, 10 WASH. U. GLOBAL STUD. L. REV. 239, 243-47 (2011) (describing bombing incident that injured Jenny Rubin and others and summarizing the litigation that followed).

117. See Campunzo, 281 F. Supp. 2d at 260; see also Kreder \& Degraaf, supra note 116, at 24347 (describing the specific injuries incurred by the Campunzo and Rubin plaintiffs); see also Rubin v. Islamic Republic of Iran, 830 F.3d 470, 473-74 (7th Cir. 2016) (providing the background of litigation in the case), cert. granted in part, 137 S. Ct. 2326 (2017).

118. Rubin, 830 F.3d at 473 .

119. Rubin v. Islamic Republic of Iran, 810 F. Supp. 2d 402, 403 (D. Mass. 2011), aff'd, 709 F. 3d 49 (1st Cir. 2013); Rubin v. Islamic Republic of Iran, 33 F. Supp. 3d 1003, $1005-06$ (N.D. Ill. 2014), aff'd, 830 F.3d 470 (7th Cir. 2016); see also Kreder \& Degraaf, supra note 115, at 242, 25154 (providing overviews of the First and Seventh Circuit suits).
} 
not qualify as property of Iran. ${ }^{120}$ The Seventh Circuit, however, found that one collection of assets held at the University of Chicago's Oriental Institute, the Persepolis Collection, met the two threshold requirements for attachment under $\S 1610$ of the FSIA. ${ }^{121}$

The Persepolis Collection, also known as the Persepolis Fortification Archive ("the PFA"), arrived at the University of Chicago Oriental Institute in the mid-1930s, as a long-term loan from the Iranian Government for "study and analysis" at the Institute. ${ }^{122}$ Consisting of tens of thousands of clay tablets and fragments, the PFA contains administrative records of the Persepolis region in southwestern Iran from approximately 500 B.C. ${ }^{123}$ The records contain information about the "daily lives of ordinary people living in the Persian Empire" and were written primarily in the rarely studied Elamite language. ${ }^{124}$ Counsel for the Rubin plaintiffs, David Strachman, indicated that he sought to attach, and then sell, the PFA tablets to help execute the judgment owed to the Rubins after reading about the research done by the Oriental Institute and their interactions with Iran. ${ }^{125}$ However, others feared that selling the tablets and potentially breaking up the PFA collection would undermine their cultural significance. ${ }^{126}$ In addition to harming the collection itself, Gil J. Stein, Director of the Oriental Institute, specified that attaching the PFA tablets could strain the tenuous relationship between the United States and Iran further and "do irrevocable harm to scholarly cooperation and cultural exchanges throughout the world."127 "Cultural heritage and

120. Rubin, 709 F.3d at 58.

121. Rubin, 830 F.3d at $473-74$.

122. Persepolis Fortification Archive, U. OF CHI., THE ORIENTAL INST., https://oi.uchicago.edu/research/projects/persepolis-fortification-archive (last visited Sept. 30, 2017); see also Claire R. Thomas, Note, "That Belongs in a Museum!" Rubin v. Iran: Implications for the Persian Collection of the Oriental Institute of the University of Chicago, 31 LOY. L.A. INT'L \& COMP. L. REv. 257, 261-66 (2009) (providing additional background information regarding the Persepolis Collection and its role in the Rubin litigation).

123. Persepolis Fortification Archive, supra note 122.

124. Thomas, supra note 122, at 264.

125. Alicia M. Hilton, Terror Victims at the Museum Gates: Testing the Commercial Activity Exception Under the Foreign Sovereign Immunities Act, 53 VILL. L. REV. 479, 494-95 (2008). "Whether [the tablets] fetch, you know, $\$ 100$ or $\$ 100,000$ or $\$ 100$ million, whatever funds are raised should be [used] to compensate the victims," Strachman told NPR in 2006. Cheryl Corley, Fight Over Ancient Persian Tablets Goes to U.S. Court, NPR (July 17, 2006, 6:00 AM) [hereinafter Fight], http://www.npr.org/templates/story/story.php?storyId=5562022.

126. Professor Matthew Stolper's, of the Oriental Institute, comments suggest that "the true significance of the tablets lies in the story they tell as a comprehensive unit," not in their individual capacities. Thomas, supra note 122, at 265-66 (citing comments from Matthew Stolpher's interview with NPR in Fight, supra note 125).

127. Gil J. Stein, A Heritage Threatened: The Persepolis Tablets Lawsuit and the Oriental 
scholarship," Stein wrote passionately in 2007, "must transcend politics." 128

The Rubin plaintiffs sought "to attach and execute on Iranian assets in order to satisfy the[ir] judgment" for over ten years. ${ }^{129}$ Despite a number of procedural issues, ${ }^{130}$ their most recent attempt to seize the PFA tablets began in the Eastern Division of the United States District Court for the Northern District of Illinois. ${ }^{131}$ The Rubins and Iran differed on three primary points. First, the parties disagreed about whether the Oriental Institute was Iran's "agent" within the meaning of the statute and whether "studying and displaying the artifacts constitute[d] "commercial activity" and thus made them attachable under $\S 1610$ (a). ${ }^{132}$ Second, the parties argued over the applicability of TRIA to certain collections at issue, which would render arguments about the use of $\S 1610(\mathrm{~g})$ unnecessary. ${ }^{133}$ Finally, the parties diverged over whether $\S 1610(\mathrm{~g})$ was a freestanding exception to state sovereign immunity under the FSIA, allowing "execution against all terror states' assets" regardless of whether or not the assets also met the requirements of $\S 1610$ (a) or (b). ${ }^{134}$ The court granted summary judgment in favor of the several defendants, including the University of Chicago and the Oriental Institute. ${ }^{135}$ The court held "there [was] no evidence that the Institute may properly be considered an agent of Iran," denying attachment under $\S 1610(a){ }^{136}$ The court also held the PFA tablets were not frozen or blocked assets, making TRIA inapplicable. ${ }^{137}$ Finally, the court held $\S 1610(\mathrm{~g})$ was not a freestanding immunity exception because the plaintiffs provided "virtually no support for their contention that Section $1610(\mathrm{~g})$ expands the bases for attachment"

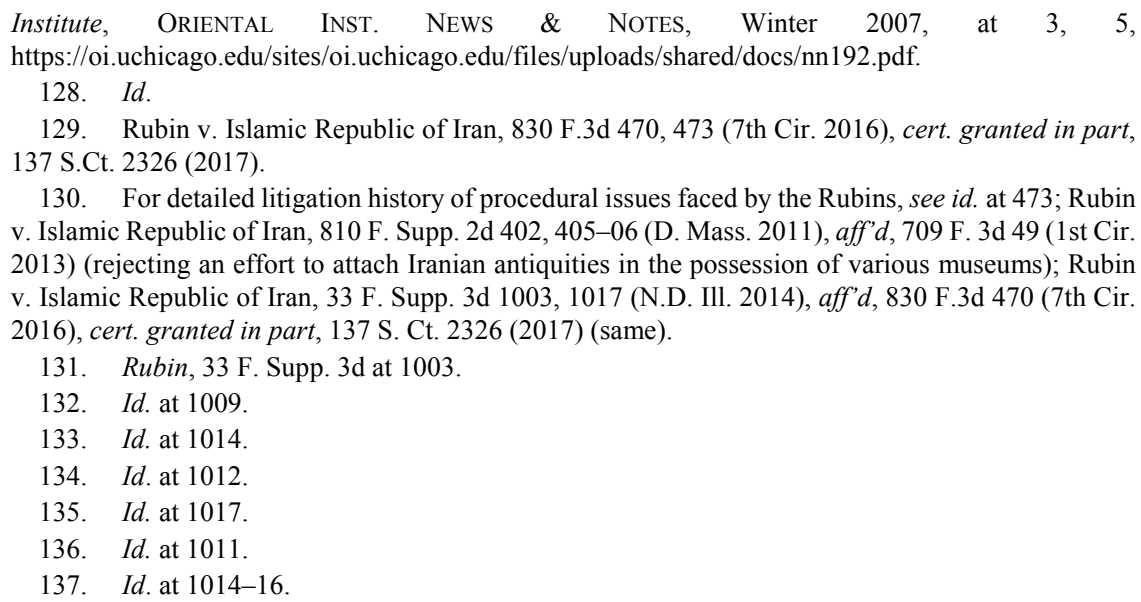

130. For detailed litigation history of procedural issues faced by the Rubins, see id. at 473; Rubin v. Islamic Republic of Iran, 810 F. Supp. 2d 402, 405-06 (D. Mass. 2011), aff'd, 709 F. 3d 49 (1st Cir. 2013) (rejecting an effort to attach Iranian antiquities in the possession of various museums); Rubin v. Islamic Republic of Iran, 33 F. Supp. 3d 1003, 1017 (N.D. Ill. 2014), aff'd, 830 F.3d 470 (7th Cir. 2016), cert. granted in part, 137 S. Ct. 2326 (2017) (same).

131. Rubin, 33 F. Supp. 3d at 1003.

132. Id. at 1009 .

133. Id. at 1014.

134. Id. at 1012 .

135. Id. at 1017 .

136. Id. at 1011 .

137. Id. at 1014-16. 
and further, the plain language of the subsection did not support their assertion. ${ }^{138}$ The plaintiffs appealed to the Seventh Circuit. ${ }^{139}$

b. The Seventh Circuit's Analysis and Ruling

A three-judge panel of the Seventh Circuit Court of Appeals affirmed the ruling of the district court, holding neither $\S 1610$ (a) nor TRIA supported the attachment of the PFA tablets, and that $\S 1610(\mathrm{~g})$ was not a freestanding exception to foreign sovereign immunity. ${ }^{140}$ First, drawing on support from the United States' amicus curiae brief in support of the appellees, and decisions of the Fifth, Second, and Ninth Circuits, the panel held that under $\S 1610$ (a), regardless of whether or not "academic study qualifies as a commercial use[,] . . a foreign state may lose its execution immunity only by its own commercial use of its property in the United States." 141 In this case, the University of Chicago was using the property, not Iran. ${ }^{142}$ Second, the panel held that TRIA did not apply because the PFA collection was "unblocked" property after President Carter's executive orders implementing the Algier Accords, and therefore, owned solely by Iran. ${ }^{143}$ Finally, the panel held that $\S 1610(\mathrm{~g})$ was not a freestanding exception to immunity, directly opposing the Ninth Circuit's holding in Bennett. ${ }^{144}$

The Seventh Circuit panel first compared the language of $\S 1610(\mathrm{~g})$ to the factors derived from Bancec, coming to the same conclusion as the Ninth Circuit in Bennett and providing a chart comparing the language of

\footnotetext{
138. Id. at 1013 .

139. Rubin v. Islamic Republic of Iran, 830 F.3d 470, $473-74$ (7th Cir. 2016), cert. granted in part, 137 S. Ct. 2326 (2017).

140. Id. at 48687.

141. Id. at 479-80; see also Brief of the United States as Amicus Curiae Supporting Appellees at 13, Rubin v. Islamic Republic of Iran, 830 F.3d 470 (7th Cir. 2016) (No. 14-1935) ("By its plain text, Section $1610(\mathrm{~g})$ makes clear that it applies only where property is otherwise attachable 'as provided in this section.' Section 1610 elsewhere requires that a foreign state's attachable property have been 'used for a commercial activity in the United States,' and Section $1610(\mathrm{~g})$ carries forward this requirement.") (citation omitted); Aurelius Capital Partners, LP v. Republic of Argentina, 584 F.3d 120, 131 (2d Cir. 2009) (establishing that funds had to be used for commercial activity by the state or a state entity prior to attachment); Af-Cap, Inc. v. Chevron Overseas (Congo) Ltd., 475 F.3d 1080, 1090-91 (9th Cir. 2007) (adopting the Fifth Circuit's commercial activity test); Conn. Bank of Commerce v. Republic of Congo, 309 F.3d 240, 256 n.5 (5th Cir. 2002) (establishing that "what matters under the statute is how the foreign state uses the property, not how private parties may have used the property in the past").
}

142. Rubin, 830 F.3d at 473

143. Id.

144. Id. at 482 . 
a typical iteration of the factors from case law and $\S 1610(\mathrm{~g}){ }^{145}$ The court concluded "subsection $(\mathrm{g})$ permits a terror victim who wins a $\S 1605 \mathrm{~A}$ judgment to execute on the property of the foreign state and the property of its agency or instrumentality 'as provided in this section' but 'regardless of' the five factors." 146 In addition to holding $\S$ $1610(\mathrm{~g})(1)(\mathrm{A})-(\mathrm{E})$ were incorporated to remove the Bancec factors, the court also held that the language "as provided in this section" in $\S 1610(\mathrm{~g})$ referred to the entirety of $\S 1610$, not just $\S 1610(f)$ as the Bennett panel concluded. ${ }^{147}$ The Seventh Circuit panel found that "as provided in this section" would be an unnecessary inclusion if $\S 1610(\mathrm{~g})$ was a freestanding exception to execution immunity and thus the Bennett panel's reading would violate the "cardinal principle" that a statute should be interpreted to avoid superfluity." 148 Additionally, according to the panel, discussions of the Flatow Amendment (or $\S 1605 \mathrm{~A}$ ) would be unnecessary in $\S 1610(\mathrm{a})(7)$ and $\S 1610(\mathrm{~b})(3)$ if "subsection $(\mathrm{g})$ pave[d] a dedicated lane for all execution actions by victims of state-sponsored terrorism." "149 In other words, if $\S 1610(\mathrm{~g})$ was specifically intended to address all terror victims attempts to attach the property of state terror sponsors, the panel felt Congress would not have included references to $\S 1605 \mathrm{~A}$ in other subsections.

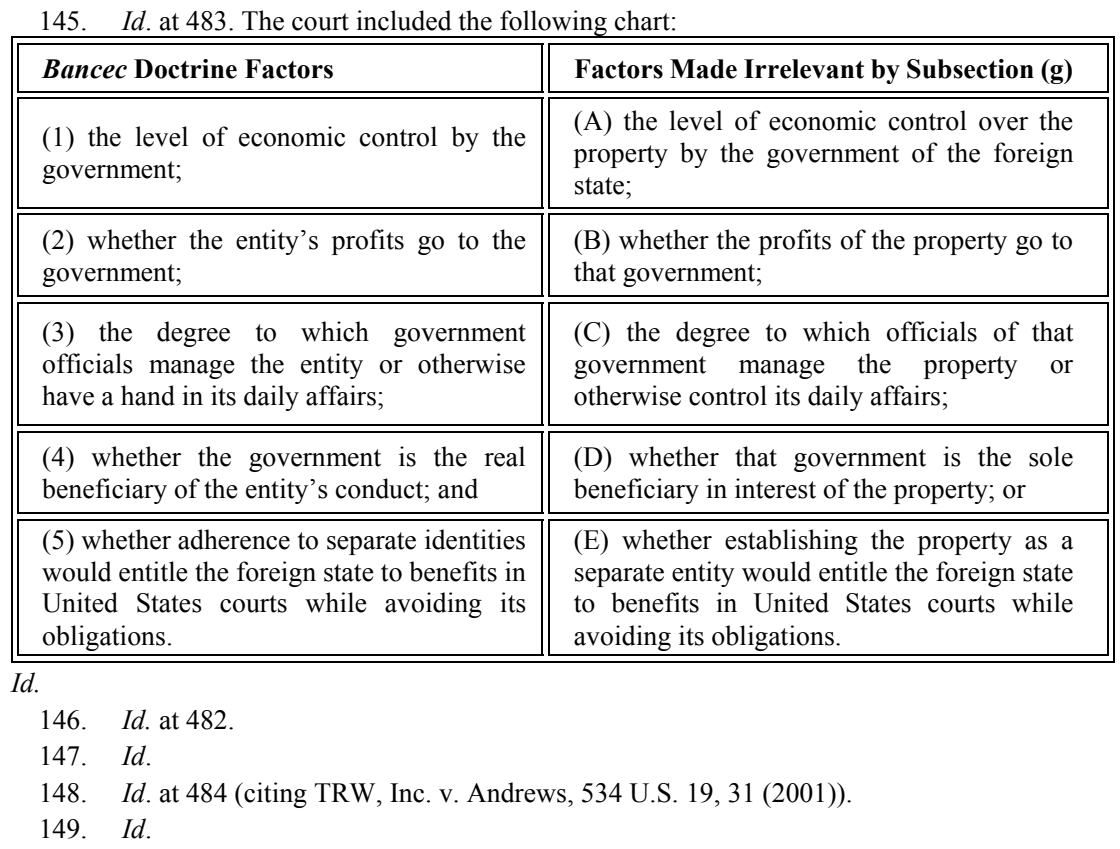


Finally, the Rubin panel directly rebutted the Bennett majority's interpretation, stating that the Ninth Circuit's interpretation that $\S 1610(\mathrm{~g})$ only applied to the preceding subsection, $\S 1610$ (f), pertaining to assets blocked by federal regulations was "highly strained." ${ }^{150}$ While $\S$ 1610(f)(1)(A) denies immunity from attachment to financial assets of state terror sponsors "blocked" by the United States under other provisions, § 1610(f)(3) allows the President to "waive any provision of paragraph (1)" of $\S 1610(\mathrm{f})$ "in the interest of national security." 151 Various Presidents have upheld a waiver of $\S 1610(f)(1)$ almost since its inclusion and this waiver has not been redacted or overridden and was in place when $\S$ $1610(\mathrm{~g})$ was enacted. ${ }^{152}$ Thus $\S 1610(\mathrm{f})$ has never been applied in any suit during $\S 1610(\mathrm{~g})$ 's existence. The Seventh Circuit panel argued that because $\S 1610(\mathrm{f})$ "never became operative," $\S 1610(\mathrm{~g})$ would "[make] no sense" if the phrase "in this section" only referred to $\S 1610(\mathrm{f}) .{ }^{153}$

The Rubin panel further found the Ninth Circuit's reliance on Gates and Wyatt was misplaced, as both cases left "the fundamental interpretive question about the scope of $\S 1610(\mathrm{~g})$... unexamined" and thus overruled the Seventh Circuit's decisions in these cases "to the extent that [the cases could] be read as holding that $\S 1610(\mathrm{~g})$ is a freestanding exception to execution immunity for terrorism-related judgments."154

Judge David Hamilton dissented, raising two primary concerns about the majority's decision. The first was a unique procedural issue outside the scope of this Comment. ${ }^{155}$ Judge Hamilton's primary argument in disagreement with the Rubin majority, however, was that the Ninth Circuit's reading of $\S 1610(\mathrm{~g})$ fits better with the legislative intent of the subsection. ${ }^{156}$ Judge Hamilton wrote:

150. Id. at 486 .

151. Id.; 28 U.S.C. 1610(f)(3) (2012). President Clinton issued a "blanket waiver" pursuant to the subsection almost as soon as it was adopted. Rubin, 830 F.3d at 486-87 (citing Presidential Determination No. 99-1, 63 Fed. Reg. 59,201 (Oct. 21, 1998)). While Congress "briefly repealed the President's waiver authority," the authority was quickly restored and the President re-waived $\S$ 1610(f)(1)'s provisions on October 28, 2000. Id. at 487; see also Presidential Determination No. 200103, 65 Fed. Reg. 66,483 (Oct. 28, 2000) (waiving § 1610(f)(1) “in the interest of national security").

152. See Rubin, 830 F.3d at 486; see also Presidential Determination No. 2001-03, 65 Fed. Reg. 66,483 .

153. Rubin, 830 F.3d at 486-87 (describing how $§ 1610$ (f) never became operative).

154. Id. at $485-87$.

155. In the Seventh Circuit, procedural rules dictate that when a panel creates a circuit split or overrules precedent, the opinion must automatically circulate within the entire court to determine "if a majority of active judges wish to rehear the case en banc." Id. at 489 (Hamilton, J., dissenting); see also supra note 15.

156. Rubin, 830 F.3d at 489-90 (Hamilton, J., dissenting). 
Both [the Bennett and Rubin courts'] readings of the text, I believe, are reasonable, meaning that the text is ambiguous. The courts must choose between two statutory readings: one that favors state sponsors of terrorism, and another that favors victims of that terrorism .... [I]n interpreting an ambiguous statutory text, we can and should draw on statutory purpose and legislative history .... The balance here should weigh in favor of the reading that favors the victims. ${ }^{157}$

\section{ANALYSIS OF $\S 1610(\mathrm{G})$ CONSTRUCTION, INTENT, AND INTERPRETATION}

The Rubin panel's interpretation of $\S 1610(\mathrm{~g})$ of the FSIA is correct for four primary reasons. First, the language and construction of 28 U.S.C. $\S 1610$ and subsection (g) support the Rubin panel's analysis. Second, the Rubin opinion and Bennett dissent conform to Congress's intent in enacting $\S 1610(\mathrm{~g})$ in the 2008 NDAA. Third, the Rubin panel's partial overruling of Gates and Wyatt was appropriate because neither case sincerely examined $\S 1610(\mathrm{~g})$. Finally, the Rubin reading of $\S 1610(\mathrm{~g})$ supports public policy concerns, including the maintenance of international diplomatic relationships and the protection of invaluable cultural antiquities.

\section{A. Language and Construction}

The language and construction of $\S 1610(\mathrm{~g})$ support the Rubin court's interpretation based on several different canons of construction. First, the traditional "plain meaning rule" dictates "the meaning of a statute must, in the first instance, be sought in the language in which the act is framed, and if that is plain ... the sole function of the courts is to enforce it according to its terms." 158 There is "no safer nor better settled canon of interpretation" than the "plain meaning rule." 159 Second, "expressio unius" is the "common sense language rule that the expression of one thing suggests the exclusion of another thing," or that intentional inclusion indicates intentional omission as well. ${ }^{160}$ Third, to determine the meaning of a statute, courts must also look to the context of particular provisions

157. Id. at 489-90 (Hamilton, J., dissenting).

158. 2A Sutherland Statutory Construction $\S 46: 1$ (Norman Singer \& Shambie Singer, eds., 7th ed. 2016) [hereinafter SUTHERLAND] (citing Caminetti v. U.S., 242 U.S. 470, 485 (1917)).

159. Id. (citing Swarts v. Siegel, 117 F. 13, 13 (8th Cir. 1902)).

160. Jacob Scott, Comment, Codified Canons and the Common Law of Interpretation, 98 GEO. L.J. 341, 351 (2010). 
within a section, statute, or act. ${ }^{161}$ Provisos, or specific conditions which must be met to appropriately apply a particular statute, often require analysis of context to determine under what circumstances they must be applied. ${ }^{162}$ Although "traditionally, a proviso restricted only the section of the act to which it was attached, or the sections which preceded it," modern courts apply "a proviso to the entire act or a single section, depending on the legislature's intention or a meaning otherwise indicated." 163

As the court discussed in Rubin, and as I argue in this Comment, the plain language of the subsection at issue only suggests the removal of Bancec considerations when claims pertain to the state-sponsored terror exception to foreign sovereign immunity, $\S 1605 \mathrm{~A} .{ }^{164}$ No language in $\S$ $1610(\mathrm{~g})$ suggests the subsection is a freestanding immunity exception for attaching any property belonging to a state sponsor of terrorism, or its instrumentalities in the United States. Additionally, the phrase "as provided in this section" should be read broadly in reference to the entirety of $\S 1610$ under the principal rules of statutory construction regarding "expressio unius" and provisos, and not narrowly as a reference only to $\S$ 1610(f). Applying $\S 1610(\mathrm{~g})$ exclusively to $\S 1610(\mathrm{f})$, or considering $\S$ $1610(\mathrm{~g})$ a freestanding immunity exception, would refer to $\S 1605 \mathrm{~A}$ claims in $\S 1610(a)$ and (b), as well as other sections of the statute and provisions of law, inappropriately superfluous.

\section{Disregarding the Bancec Factors}

A literal reading of $\S 1610(\mathrm{~g})$ suggests that the five factors of the subsection are a reference to the Bancec test. Both the Bennett and Rubin courts agree with this sentiment, but disagree about whether or not this is the only possible consequence of $\S 1610(\mathrm{~g}) .{ }^{165}$ The Bancec doctrine is often applied when determining if immunity should be granted to separate juridical entities, regardless of whether immunity is denied for the sovereign to which they are an entity. ${ }^{166}$ Nodding to the usual application of the Bancec factors, $\S 1610(\mathrm{~g})$ expressly refers to "separate juridical

\footnotetext{
161. See generally 2A SUTHERLAND, supra note 158, § 47:2.

162. See generally id. $\S 47: 9$.

163. Id.

164. Rubin v. Islamic Republic of Iran, 830 F.3d 470, 484 (7th Cir. 2016), cert. granted in part, 137 S. Ct. 2326 (2017).

165. Id. at 482-83; Bennett v. Islamic Republic of Iran, 825 F.3d 949, 955-56 (9th Cir. 2016).

166. See Bennett, 825 F.3d at 955-56.
} 
entit[ies]." 167 The language of $\S 1610(\mathrm{~g})(1)(\mathrm{A})-(\mathrm{E})$ also closely mirrors the Bancec factors as construed in Walter Fuller Aircraft Sales, Inc. v. Republic of Philippines, and applies "regardless of' those factors. ${ }^{168}$ Both the Rubin and Bennett panels agree that $\S 1610(\mathrm{~g})$ suggests ignoring the potential application of the Bancec factors to state sponsors of terror and their separate juridical entities, and thus denying terror sponsors immunity in all circumstances. ${ }^{169}$

According to the common language rule, espressio unius, expressly including only the Bancec factors as considerations that courts should disregard when applying $\S 1610(\mathrm{~g})$ indicates that these factors were the only potential concerns Congress wanted the courts to set aside when considering immunity from attachment for entities of state terror sponsors. If Congress intended $\S 1610(\mathrm{~g})$ as a freestanding immunity exception, Congress was not limited to listing only the Bancec factors as considerations to disregard. Congress could have included additional subsections pursuant to $\S 1610(\mathrm{~g})(1)$, asking courts to also disregard the "commercial use" requirements of $\S 1610$ (a) and (b), or the rest of $\S 1610$, when allowing plaintiffs to attach the assets of state terror sponsors or their separate juridical entities, but it did not.

Alternatively, Congress could also have included the proviso "notwithstanding any other provision of law" in $\S 1610(\mathrm{~g})$, as they did in TRIA $\S 201$ (a) and in $\S 1610(\mathrm{f})$. While Congress would still need to expressly include a list of Bancec factors because they are based on case law and not statutory provisions, including the language "notwithstanding any other provision of law" would make the Ninth Circuit panel's conclusion more appropriate. The omission of this phrase, or a similar phrase, indicates that the requirements of $\S 1610$ (a) and (b), as well as the rest of $\S 1610$, still apply to claims pursuant to $\S 1610(\mathrm{~g})$, even if the Bancec factors do not.

\section{2. "In This Section," Superfluity, and Word Choice}

Unlike the Ninth and Seventh Circuits' agreement over the easing of the Bancec factors under $\S 1610(\mathrm{~g})$, the panels strongly disagreed about Congress's intended meaning of "in this section." While both majorities provide compelling rationales for their opinions, the Rubin majority

\footnotetext{
167. 28 U.S.C. $§ 1610(\mathrm{~g})(1)(2012)$; see also supra notes $69-77$ and accompanying text discussing "separate juridical entities."

168. Rubin, 830 F.3d at 482-83. See also supra note 145.

169. Rubin, 830 F.3d at 482-83; Bennett, 825 F.3d at 955-56.
} 
opinion and Bennett dissent offer the more fundamentally persuasive argument - that "in this section" refers to the entirety of $\S 1610$, not just $\S$ 1610(f). Both rely on the same "cardinal principle" of statutory construction - that a statute should be read to avoid making any "clause, sentence, or word" superfluous or unnecessary. ${ }^{170}$

If $\S 1610(\mathrm{~g})$ is construed only as a reference to the subsection preceding it as the Bennett majority suggests, Congress's inclusion of references to $\S 1605 \mathrm{~A}$ in other sections would be unnecessary. ${ }^{171}$ Section $1610(a)(7)$ denies immunity from attachment to property of foreign states used for commercial activity in the United States if "the judgment relates to a claim for which the foreign state is not immune under section 1605A or section 1605(a)(7) . .."172 Section 1610(b)(3) provides the same basic rule for agencies or instrumentalities denied immunity under $\S 1605 \mathrm{~A} .{ }^{173}$ If, as the Bennett court suggests, $\S 1610(\mathrm{~g})$ is a freestanding exception to immunity, $\S 1610(\mathrm{~g})$ would automatically govern all property that plaintiffs sought to attach pursuant to $\S 1605 \mathrm{~A}$, regardless of its "commercial use," and additional references to $\S 1605 \mathrm{~A}$ in other sections of $\S 1610$, including references in $\S 1610(a)$ and (b), would be unnecessary.

Furthermore, intepreting $\S 1610(\mathrm{~g})$ 's "as provided in this section" language is a reference back to $\S 1610(\mathrm{f})$ is illogical, primarily because $\S$ $1610(\mathrm{f})$ was not operative at the time of $\S 1610(\mathrm{~g})$ 's adoption, and has never been operative since. ${ }^{174}$ Congress passed $\S 1610(\mathrm{~g})$ only eight years after President Clinton waived $\S 1610(\mathrm{f})$ for the second time. ${ }^{175}$ It is unlikely that Congress would pass an amendment dependent on subsection $\S 1610$ (f) which would be "effectively a nullity upon passage" because "Congress is presumed to legislate against the backdrop of the "known state of laws." 176 Because $\S 1610$ (f) has never been operative, reading $\S$ $1610(\mathrm{~g})$ 's grant of immunity 'exception 'as provided in [\$1610(f)]' would mean no execution at all." 177 Additionally, if $\S 1610(\mathrm{~g})$ is to be considered a freestanding immunity exception, it is unlikely that it would need to refer

\footnotetext{
170. Rubin, 830 F.3d at 484 (citing TRW Inc. v. Andrews, 524 U.S. 19, 31 (2001)); Bennett, 825 F.3d at 968 (Benson, J., dissenting) (citing TRW, 524 U.S at 31).

171. Rubin, 830 F.3d at 484-87.

172. 28 U.S.C. $\S 1610(a)(7)(2012)$.

173. Id. § 1610(b)(3).

174. Rubin, 830 F.3d at $486-87$.

175. Id.; see also supra notes $151-53$ and accompanying text.

176. Rubin, 830 F.3d at 487 (citing Voisine v. United States, 136 S. Ct. 2272, 2280 (2016)).

177. Id.
} 
back to a subsection that is in place, "notwithstanding any other provision of law," when neither subsection mentions the other expressly. To contend that a freestanding $\S 1610(\mathrm{~g})$ refers to $\S 1610(\mathrm{f})$ would be saying that one independent immunity exception is in fact dependent on another to function. This cannot be the case.

Finally, Congress's word choice and lack of specificity in the phrase, "as provided in this section," is telling. The plain meaning of the word "section" implies a broader set of inclusions than the terms: "subsection;" "paragraph;" or "subparagraph," used in other portions of $\S 1610$ and $\S$ $1610(\mathrm{~g}) .{ }^{178}$ Additionally, many of the references within $\S 1610$ to another "section" expressly refer to whole segments of law with the same level of specificity as the entirety of $\S 1610 .{ }^{179}$ "Section," as used in $\S 1610(\mathrm{~g})$ 's phrase "as provided in this section," is more likely a reference to $\S 1610$ as a whole, rather than another unspecified subsection of $\S 1610$. Instead of adopting the Bennett court's interpretation, courts should read "in this section" as referring to the entirety of $\S 1610$ as the Rubin panel did and the United States as amicus suggested in both Rubin and Bennett.

In effect, the Rubin reading would require attachments under $\S$ $1610(\mathrm{~g})$ to also have a "commercial use" under $\S 1610(\mathrm{a})$ or (b), or to comply with another subsection of $\S 1610$ before $\S 1610(\mathrm{~g})$ privileges could apply. Essentially, only when (1) the property at issue belongs to a foreign state, sued pursuant to the state-sponsored terrorism exception, $\S$ $1605 \mathrm{~A}$; and (2) the same property is subject to attachment "as provided" under subsections $\S 1610(\mathrm{a})-(\mathrm{f})$, would $\S 1610(\mathrm{~g})$ be applicable to alleviate the Bancec factor analysis. This would be the appropriate application of the "cardinal principles of statutory construction" and alleviate the issues of reading superfluity and unintended consequences into $\S 1610(\mathrm{~g})$.

\section{B. The Intent of $\S 1610(g)$}

Both the Rubin and Bennett panels agreed that Congress included $\S$ $1610(\mathrm{~g})$ in the $2008 \mathrm{NDAA}$ as a response to the ongoing struggles terror victims had in attempting to execute their court ordered judgments against Iran. ${ }^{180}$ While there is no doubt Congress sought to make this process

\footnotetext{
178. See $\S 1610$ (b) ("In addition to subsection (a) ....").

179. See id. at $\S 1610(\mathrm{a})(7)$.

180. See Rubin, 830 F.3d at 481 ("The other major change was the creation of $\S 1610(\mathrm{~g})$, which applies to execution proceedings to enforce judgments obtained under $\S 1605 \mathrm{~A}$ and eases the collection process for victims of state-sponsored terrorism.”); Bennett v. Islamic Republic of Iran, 825
} 
easier for sympathetic plaintiffs, the courts disagreed about how much Congress intended to abrogate the preexisting requirements for attachment. ${ }^{181}$ While the Rubin court's reading of $\S 1610(\mathrm{~g})$ suggests a less extreme step toward easing attachment requirements for terror victims, this reading is substantially more prudent than the Bennett panel's interpretation, particularly in light of the assets at issue in Rubin.

Under the Bennett court's interpretation of $\S 1610(\mathrm{~g})$, " any and all Iranian property in the United States" could be attached to aid in execution of a terror victim's judgment. ${ }^{182}$ The courts have already limited attachment under $\S 1610(\mathrm{~g})$ by holding that a "plain reading of $\S 1610(\mathrm{~g})$ offers no indication that Congress intended to eliminate the immunity that has long been afforded to diplomatic properties ...."183 Therefore, $\S$ $1610(\mathrm{~g})$ cannot allow for the attachment of all Iranian property because particular property maintains immunity for diplomatic purposes. ${ }^{184}$ While the Ninth Circuit's interpretation would provide more attachable assets for terror victim plaintiffs to apply toward their judgments, this reading goes against case precedent that limits the kinds of assets that can be seized. ${ }^{185}$

The Rubin court's reading of $\S 1610(\mathrm{~g})$, by contrast, benefits plaintiffs by simply removing the presumed Bancec factor considerations generally required to attach separate juridical entities of a foreign sovereign in aid of execution. ${ }^{186}$ Allowing for the attachment of separate juridical entities, like Bank Melli, without requiring that the entity meets one of the Bancec exceptions opens up potential attachment options not permissible prior to the 2008 NDAA. ${ }^{187}$ That the United States, through amicus briefs filed in both Bennett and Rubin, agrees with the Rubin panel is also a strong indication the majority in Rubin has correctly interpreted Congress's intent to simply remove the generally required application of Bancec under $\S 1610(\mathrm{~g}) .{ }^{188}$

\footnotetext{
F.3d 949, 955-56 (9th Cir. 2016) (“Congress responded by enacting new statutes, this time designed to facilitate the satisfaction of such judgments by expanding successful plaintiffs' ability to attach and execute on the property of agencies and instrumentalities of terrorist states.").

181. Rubin, 830 F.3d at 486; Bennett, 825 F.3d at, 960.

182. 825 F.3d at 969 (Benson, J., dissenting) (emphasis added).

183. In re Islamic Republic of Iran Terrorism Litig., 659 F. Supp. 2d 31, 102 (D.D.C. 2009).

184. Bennett, 825 F.3d at 969 (Benson, J., dissenting).

185. Id.

186. Rubin, 830 F.3d at 487 .

187. See also Bank Markazi v. Peterson, 136 S. Ct. 1310, 1329 (2016) (approving attachment of Bank Markazi, a separate juridical entity of Iran under 22 U.S.C. $\S 8772$ ).

188. Brief for the United States as Amicus Curiae Supporting Appellees at 25-26, Rubin v. Islamic Republic of Iran, 830 F.3d 470 (7th Cir. 2016) (No. 14-1935); Brief for the United States as Amicus Curiae Supporting Neither Party at 9-10, Bennett v. Islamic Republic of Iran, 825 F.3d 949
} 
Certain members of Congress have started taking steps to clarify $\S$ $1610(\mathrm{~g})$ to prevent plaintiffs from seeking to attach cultural antiquities, particularly in the future, suggesting that courts permitting attachment of cultural antiquities was unanticipated or undesired. ${ }^{189}$ The Foreign Cultural Exchange Jurisdictional Immunity Clarification Act, enacted in December 2016, created a new subsection (h) to 28 U.S.C. $\S 1605 .{ }^{190}$ This subsection, entitled "Jurisdictional immunity for certain art exhibition activities," dictates that interactions between the United States and foreign entities to facilitate display or temporary exhibition of foreign works that meet the requirements of the Immunity From Seizure Act ("IFSA") do not constitute "commercial use" within the sense of FSIA, or open foreign entities up to suit in the United States. ${ }^{191}$ The committee report on the version of the Act's initial proposal that originated in the House explains that "[f]oreign governments are discouraged from such lending by the possibility that it will open them up to litigation in U.S. courts for which they would otherwise be immune. This legislation fixes this problem by making a narrowly tailored change to FSIA."192 While the Act fails to specifically address the issue of potential immunity under $\S 1610$, by clarifying the "commercial use" question, the Act suggests that $\S 1610(a)$, the "commercial activity" requirement for attachment, would likely apply to $\S 1610(\mathrm{~g}){ }^{193}$ Although the Seventh Circuit's understanding of $\S$ $1610(\mathrm{~g})$ provides fewer options for plaintiffs than the Bennett panel might have hoped, it still partially fulfills Congress's goal of making it easier to compensate terror victims without going beyond the reasonable bounds Congress likely intended.

\section{The Propriety of Overruling Precedent}

The Seventh Circuit also appropriately overruled portions of their previous decisions in Gates and Wyatt. As the court pointed out, neither Gates nor Wyatt thoroughly considered the meaning of $\S 1610(\mathrm{~g}) .{ }^{194}$ Instead, the courts in Gates and Wyatt left the subsection as an

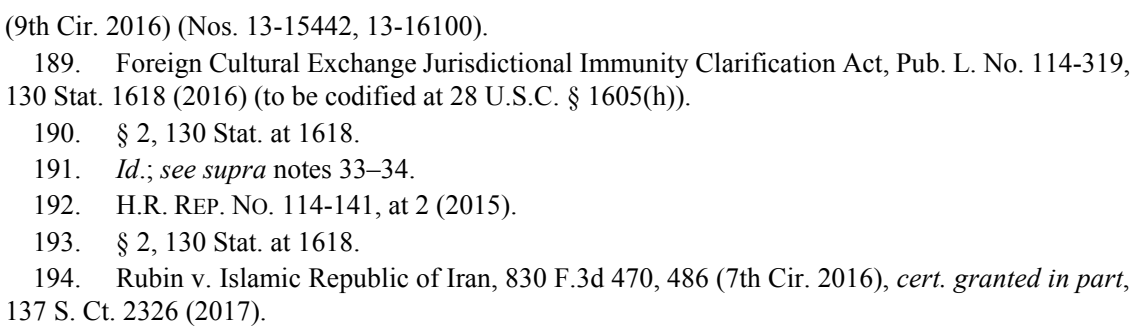


"unexamined premise."195 Neither case required a deep analysis of $\S$ $1610(\mathrm{~g})$ because other provisions of the FSIA provided for attachment of the assets of foreign state sponsors of terror sought by the plaintiffs in those cases. ${ }^{196}$ By overruling Gates and Wyatt to the extent that they could be understood as "holding that $\S 1610(\mathrm{~g})$ [was] a freestanding exception to execution immunity for terrorism-related judgments," the panel correctly maintained the primary holdings of the cases and attempted to prevent future misunderstanding of $\S 1610(\mathrm{~g}) .{ }^{197}$ While even partially overruling Seventh Circuit precedent may be procedurally problematic in this case, the panel acted appropriately here because the primary holdings and judgments in both cases remain. ${ }^{198}$

\section{Public Policy Concerns}

In cases like Rubin and Bennett courts often find themselves in scenarios similar to those Dr. Jones faces throughout the Indiana Jones movies - forced to choose between a pit filled with poisonous snakes and a room full of creepy-crawly beetles. On one hand, the courts aim to support terror victims by helping provide justice and compensation for their suffering; on the other hand, courts are forced to consider the educational, political, and diplomatic ramifications of denying foreign state-sponsors of terror immunity, seizing their assets, or sometimes, allowing their cultural treasures to be sold off to the highest bidder who may not fully appreciate their worth. The FSIA seeks to ameliorate some of the "case-by-case diplomatic pressures" associated with cases like Rubin and Bennett, but simply cannot remove them all. ${ }^{199}$ In these kinds of cases it is essential for courts to consider issues of public policy. Here, the Seventh Circuit appropriately read $\S 1610(\mathrm{~g})$ to protect the PFA tablets and allow them to remain where they can generate the most value to society. ${ }^{200}$

When comparing the decisions of Bennett and Rubin, it is important to first compare the kinds of assets each set of plaintiffs attempted to attach

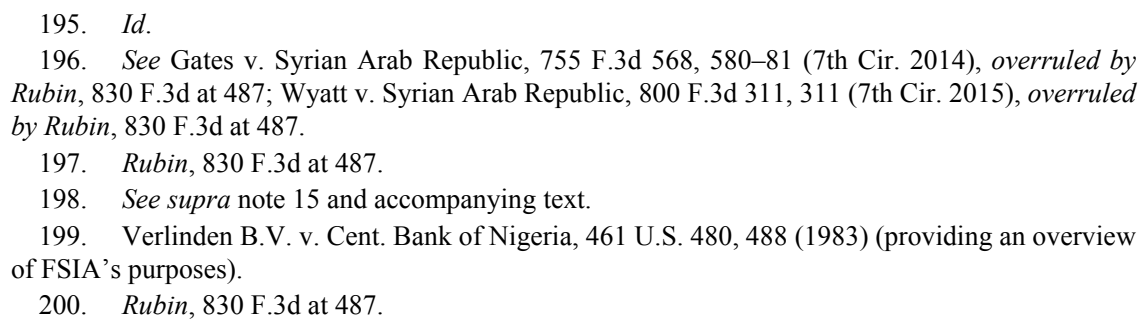


to satisfy their judgment. In Bennett, the plaintiffs sought financial assets, a standard form of compensatory or punitive damages in civil suits. ${ }^{201}$ Money is commonplace and not imbued with any sentimental, academic, or cultural value. Unlike the antiquities sought by the plaintiffs in Rubin, financial assets are not something that can be entirely lost or destroyed and never replaced. In fact, due to the nature of financial assets sought in Bennett, the Ninth Circuit was not required to consider $\S 1610(\mathrm{~g})$ at all. The financial remedy the Bennett plaintiffs sought was reachable under the TRIA $\S 201$ (a), "notwithstanding any other provision of law."202 Because there was no question the TRIA allowed for the attachment of Iranian assets blocked or frozen by the U.S. government, which included the Visa and Franklin funds, the Ninth Circuit did not need to look elsewhere or redefine other areas of the law, like $\S 1610(\mathrm{~g})$, to reach the plaintiffs' objective. ${ }^{203}$

Unlike money, antiquities, and in particular the PFA tablets sought by the Rubin plaintiffs, are unique and irreplaceable. Not only do the PFA tablets include some of the oldest writings in the world, but they are also held by the institution that can most likely best utilize them. ${ }^{204}$ The University of Chicago's Oriental Institute is one of the few academic institutions in the world with so many scholars versed in Persian history and able to read the nearly dead Elamite language. ${ }^{205}$ Additionally, unlike most financial assets, it is entirely impossible to replace historical artifacts like those in the PFA collection, important to Iranian citizens and global scholars alike. If the Rubin plaintiffs were to be awarded the PFA tablets, they would likely sell them, perhaps to buyers who would not, or could not, provide the same level of care as the University of Chicago. ${ }^{206}$ In addition, according to scholars, the collection is best viewed as a whole rather than in fragments. ${ }^{207}$ Selling off parts of the collection could destroy the historical integrity and academic value of the collection, undoing the eighty years of scholarly inquiry pursued by the Oriental Institute, and

\footnotetext{
201. Bennett v. Islamic Republic of Iran, 825 F.3d 949, 954 (9th Cir. 2016).

202. Terrorism Risk Insurance Act of 2002, Pub. L. No. 107297, § 201(a), 116 Stat. 2322, 2337 (codified as amended in scattered sections of 12 U.S.C., 15 U.S.C., and 28 U.S.C.).

203. Bennett, 825 F.3d at 96970 (Benson, J. concurring).

204. Stein, supra note 127 , at 3.

205. Id. ("This extremely di $\square$ cult language can be read by only a tiny number of highly- trained researchers, perhaps no more than twenty or so throughout the world.")

206. See Fight, supra note 125; Thomas, supra note 122, at 286-88 (discussing the implications of attaching the tablets to the Rubin judgment in section "VIII. Implications of the Lawsuit").

207. Fight, supra note 125.
} 
causing the collection to, both metaphorically and perhaps physically, crumble. ${ }^{208}$

Historically, the United States has both aimed to maintain diplomacy and sometimes repair broken diplomatic relationships with other nations through the preservation of antiquities. One simple step toward maintaining these goals would be to adopt the Seventh Circuit's understanding of the FSIA $\S 1610(\mathrm{~g})$, which is also supported by the United States. ${ }^{209}$ The ramifications of allowing plaintiffs to seize "national treasures" like the PFA tablets would be severe and counterproductive in repairing connections with Iran, and maintaining relationships with nations around the globe. Today, the United States, through the IFSA, seeks to protect artifacts on loan from foreign nations, like the PFA tablets, from judicial proceedings in the United States. ${ }^{210}$ Unfortunately, because IFSA was enacted long after Iran loaned the PFA collection to the United States in 1936, there is no current legislation protecting the tablets. ${ }^{211}$ The courts, however, can protect the PFA tablets through the appropriate, limited interpretation of $\S 1610(\mathrm{~g})$. If the United States allowed attachment of the PFA tablets to satisfy the Rubins' judgment, it would likely set a negative example internationally. Seeing the United States attach antiquities could make other nations less likely to loan their artifacts to the United States in the future, a devastating blow to international cultural understanding and its global diplomacy. ${ }^{212}$ Additionally, U.S. museums and institutions fear that U.S. courts seizing foreign antiquities may open the United States up to reciprocal treatment. ${ }^{213}$

208. See id.; Thomas, supra note 122, at 286-88 (discussing the implications of attaching the tablets to the Rubin judgment in section "VIII. Implications of the Lawsuit").

209. See Rubin v. Islamic Republic of Iran, 830 F.3d 470 (7th Cir. 2016); Brief for the United States as Amicus Curiae Supporting Appellees at 10, Rubin, 830 F.3d 470 (2016) (No. 14-1935); Brief for the United States as Amicus Curiae Supporting Neither Party at 10, Bennett v. Islamic Republic of Iran, 825 F.3d 949 (2016) (Nos. 13-15442, 13-16100).

210. 22 U.S.C. $\$ 2459$ (2012).

211. See supra notes 33-34. IFSA does not apply to the PFA tablets because for IFSA protection to apply, the "President or his designee" must find an object is "of cultural importance," the activity within the U.S. is "in the national interest," and must publish a notice indicating the findings in the Federal Register prior to importing the object. § 2459. Because the tablets were loaned to the United States in the 1930s, before IFSA was in place, the tablets could not have received a presidential designation prior to import.

212. See Thomas, supra note 122, at 286-88 (discussing the possible effects of attaching the tablets to the Rubin judgment in section "VIII. Implications of the Lawsuit"); Lopez, supra note 30.

213. Lopez, supra note 30 ("It is not surprising that foreign sovereigns, the U.S. Government, and U.S. museums are extremely concerned about these lawsuits [like Rubin]. Foreign sovereigns are, quite obviously, concerned because they do not want their national treasures confiscated. The U.S. Government meanwhile fears reciprocal treatment of U.S. national treasures abroad. For their part, U.S. museums are concerned for two reasons: (a) they worry that foreign nations will stop loaning 
While the United States has long been at political odds with Iran, in part due to the nation's support of terror attacks on U.S. citizens, taking away objects of cultural significance would punish not only Iran, but the likely innocent scholars, nationally and internationally, who might seek to study the PFA tablets. ${ }^{214}$ Consider $\S 1610(\mathrm{~g})(3)$, which aims to protect against "the impairment of an interest held by a person who is not liable in the action giving rise to a judgment in property subject to attachment in aid of execution." 215 While $\S 1610(\mathrm{~g})(3)$ does not apply to Rubin because the Oriental Institute holds no valid property right to the tablets, only a temporary right to possession while the tablets are on loan, the Oriental Institute does maintain a strong interest in the preservation and protection of the collection for academic purposes.

Though the potential seizure of the PFA tablets arose under a very specific set of circumstances, the likelihood of similar circumstances arising in the future may continue to grow in light of the Justice Against State Sponsors of Terror Act. ${ }^{216}$ The Act particularly denies immunity "from the jurisdiction of the courts of the United States in any case in which money damages are sought" to countries supporting specified terror acts against the U.S. ${ }^{217}$ Although the Saudi Arabian assets available in the United States are likely less scarce and intrinsically different from those of Iran, it is almost certain that battles over Saudi Arabian valuable antiquities, like the Iranian PFA tablets, could arise in the near future if Saudi Arabia, like Iran, refuses to pay judgments held against them. ${ }^{218}$ Adopting the Rubin court's view would protect only a very narrow kind of property, only that which is not commercially used, while permitting plaintiffs to bypass the Bancec doctrine to reach assets of separate juridical entities of state sponsors of terror.

\footnotetext{
valuable collections to U.S. institutions, and (b) they worry about their own legal exposure, should a loan temporarily in their possession for exhibit or scholarship become entangled in an FSIA lawsuit.").

214. See Stein, supra note 126, at 5 (arguing for the protection of the PFA tablets as a piece of the "shared heritage of all people").

215. 28 U.S.C. $\$ 1610(\mathrm{~g})(3)(2012)$; see also supra note 130 and accompanying text.

216. See supra notes 16-17 and accompanying text.

217. Justice Against Sponsors of Terrorism Act, Pub. L. No. 114-222, 130 Stat. 852 (2016) (to be codified, in part, at 28 U.S.C. $\S 1605 B)$.

218. Opinion, An Obama Veto Worth Backing, WALl StREET J. (Sept. 20, 2016, 7:21 PM), http://www.wsj.com/articles/an-obama-veto-worth-backing-1474413692.
} 


\section{RESOlVING THE CIRCUIT SPLIT AND MOVING FORWARD}

Moving forward, the Rubin interpretation of $\S 1610(\mathrm{~g})$ could be nationally applied in two ways. First, the Legislature could act to amend the language in segments of the FSIA to clarify $\S 1610(\mathrm{~g})$ 's intended purpose. Alternatively, the Supreme Court could adopt the Seventh Circuit's interpretation. Parties in both cases have filed petitions for writs of certiorari. ${ }^{219}$ The Rubin petition, filed by the plaintiffs, asked the Court to clarify $\S 1610(\mathrm{~g})$ and $\S 1610(\mathrm{a})$, while the Bennett petition, filed by the defendant Bank Melli, only sought clarification of $\S 1610(\mathrm{~g}){ }^{220}$ In June 2017 , the Court granted certiorari to address only the meaning of $\S$ $1610(\mathrm{~g}){ }^{221}$ The Court will likely wait to take further action in Bennett until Rubin has been decided on the merits. ${ }^{222}$

\section{CONCLUSION}

After years of struggling his way through trains of wild animals, surviving dramatic fights with thieves and miscreants, and narrowly avoiding certain death by escaping a sinking, later exploding, ship Indiana Jones eventually placed Coronado's crucifix into the hands of a museum curator. ${ }^{223}$ While Jones's plight makes for great cinema, we should not require foreign sovereigns or American museums seeking to preserve historical artifacts to jump through judicial hoops to retain their cultural treasures against court orders. The Rubin panel's reading of $\S 1610(\mathrm{~g})$, limiting $\S 1610(\mathrm{~g})$ to merely removing the Bancec requirements usually applied to separate juridical entities and not serving as a "free-standing immunity exception," should be nationally implemented in order to prevent the seizure of cultural antiquities in the future. Based on the language and structure, Congressional intent, the propriety of overruling Seventh Circuit precedent, and the policy concerns associated with $\S$ $1610(\mathrm{~g})$, the Rubin reading is a more appropriate balance between providing foreign sovereign immunity and compensating terror victims for their suffering.

219. Petition for Writ of Certiorari, Rubin v. Islamic Republic of Iran, 2016 U.S. S. Ct. Briefs LEXIS 3798 (2016) (No. 16-534); Petition for Writ of Certiorari, Bank Melli v. Bennett, 2016 U.S. S. Ct. Briefs LEXIS 3370 (2016) (No. 16-334).

220. Petition for Writ of Certiorari, Rubin, supra note 219, at *7-8; Petition for Writ of Certiorari, Bennett, supra note 219 , at *8.

221. Rubin v. Islamic Republic of Iran, 137 S. Ct. 2326 (2017).

222. Amy Howe, Federal Government Files Invitation Briefs, SCOTUSblog (May 26, 2017, 7:24 PM), http://www.scotusblog.com/2017/05/federal-government-files-invitation-briefs/.

223. INDIANA JONES AND THE LAST CRUSADE (Lucasfilm Ltd. 1989). 
Congress could remedy the confusion by passing additional legislation to clarify its intent in enacting $\S 1610(\mathrm{~g})$. In the meantime, the Supreme Court should read $\S 1610(\mathrm{~g})$ as eliminating the Bancec factors for the attachment of assets to compensate terror victims, but not as a freestanding immunity exception allowing for the seizure of any asset, regardless of the other requirements of $\S 1610(\mathrm{~g})$. The language and construction of $\S 1610(\mathrm{~g})$, the intent of Congress, and diplomatic and cultural public policy concerns support a narrow reading of $\S 1610(\mathrm{~g})$. So, likely, would Indiana Jones. 